$$
\begin{aligned}
& \text { أسالبب الشرح والإيضاح } \\
& \text { ومغاماتها } \\
& \text { في التربية والتوجبب } \\
& \text { دراسة بلاغية تطبيقية } \\
& \text { د. محمـد بـن عبد الرحمـن الحراز } \\
& \text { أستاذ البلاغة والنقـد الأدبي المشـارك } \\
& \text { في قسـم اللغة العربية وآدابها } \\
& \text { بكامعة القصيم } \\
& \rightarrow 1 \leq r 0-1 \leqslant r \leqslant
\end{aligned}
$$


$$
-V 17-
$$ 


$$
\text { بسم الله الرحمن الرحيم }
$$

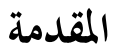

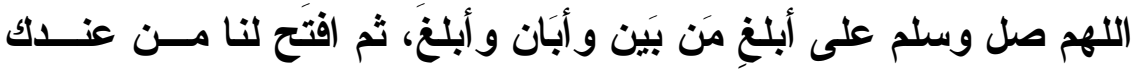
فتحا مبينا بليغا نافعا، وأنت خير الفاتحين، أما بعد:

فإن حس التربية و التوجيه لا يمكن بحال من الأحوال أن ينفك عن أحسـ

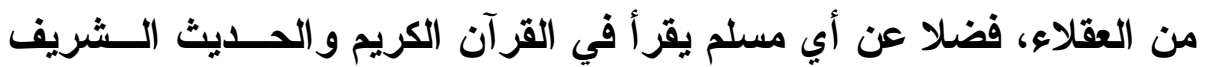

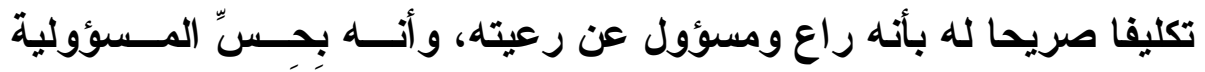
و التبليغ صارت أمته خير أمة أخرجت للناس.

ومن هذا المنطلق تَتَفت العين ويُعمل الفكر بحثا عـن ألطــف الطــرق لإحداث التغيير الإيجابي المطلوب، ولما كان اللسان هو الطريق الثائع مسن

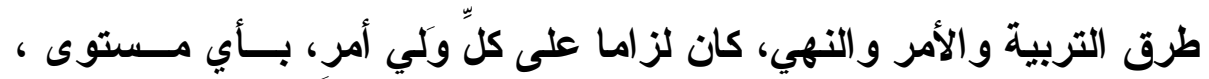

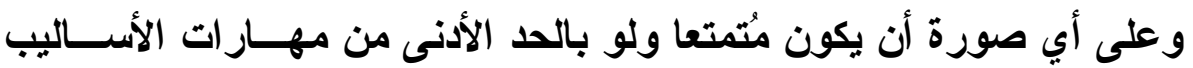

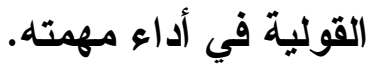

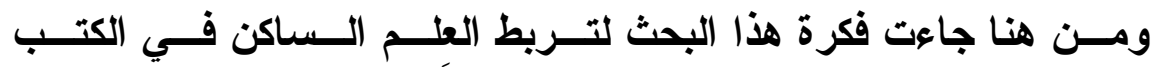

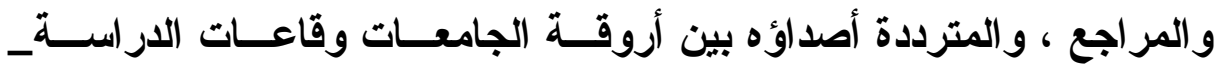

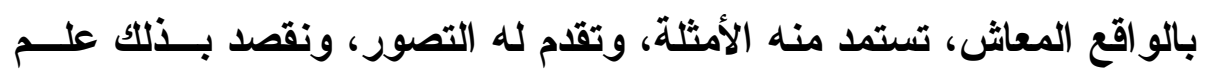

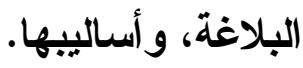

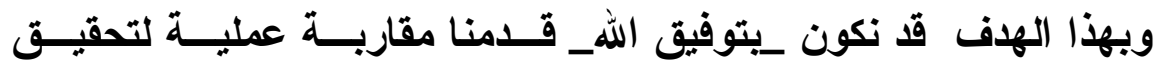


الأول: هلف علمي بحت، وهو إحياء علم البلاغة، أو الإسهام في إحيائه وربطه بالو اقع، وتيسير قو اعده، وإخلاؤها من أثقال التقسيمات و التفريعسات و التعريفات التي لا يستدعيها الواقع التطبيقي ولا يتطلبها الأداء العملي.

الثاني: تزويد المربي المهتم، و الواعظ المتحمس، والداعيــة المتـــدر،

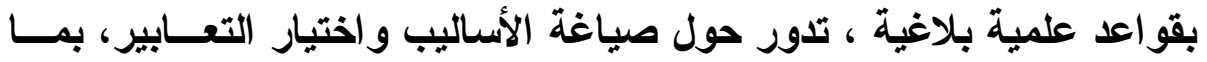

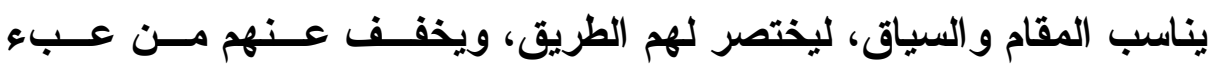

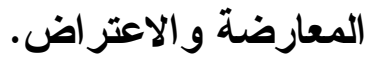

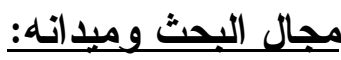

إن البحث في هذه الأساليب وألو انها وتطبيقاتها أوسع مـن أن يحويــهـ

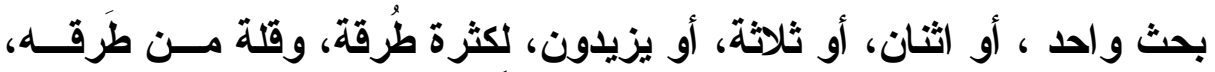

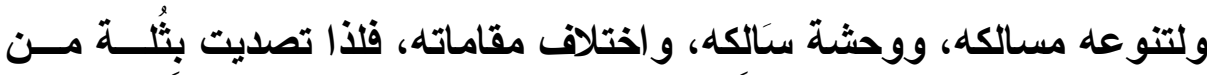
البحوث البلاغية المرتبطة ارتباطا وثيقا بالتطبيقات العصرية؛ فقدمت بحثين وفين

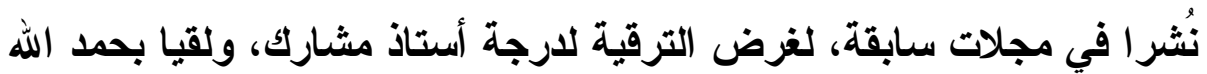

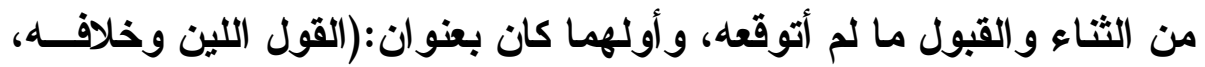
في الأمر بالمعروف و النهي عن المنكر، المفهوم والتطبيقات، دراسة بلاغيــة

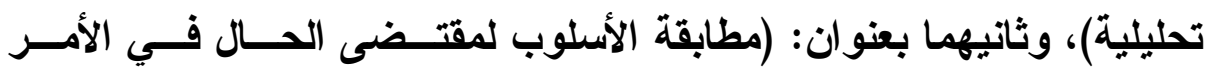
بالمعروف و النهي عن المنكر، صوره وتطبيقاته، دراسة بلاغية تحليلية). وها أنا ذا اثفع هذين البحثين بثالثهما، ليزيد فــي إيـضاح الأســاليب

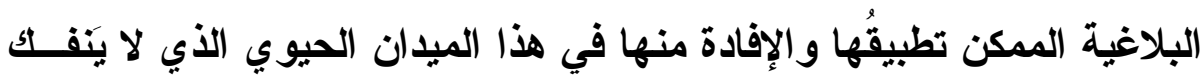
يتر اءى أمام أعينتا في كل لحظة وآن. 


\section{منهجج البحث:}

يقوم البحث على منهج التحليل والمقارنة والتقييم.

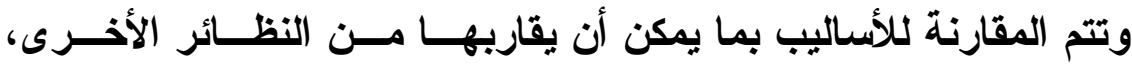

للوصول إلى الهذف من هذا البحث، وهو تقييم تلك المواقف تقييمـــا بلاغيــا علميا، من خلا النظر في علاقة الأثر بالأسلوب البلاغي المستعمل.

وقد جاء هذا البحث في ثنلاثة مباحث؛ تُبرز ما يحتاج إليه عنوانــه مــن

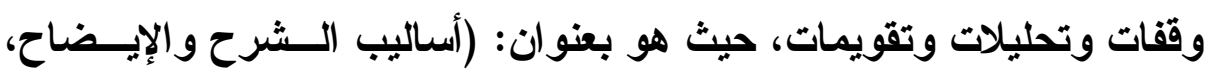

ومقاماتها؛ في التربية و التوجيه).

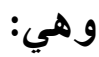

المبحث الأول: بلاغة التفصيل والإيضاح بأساليب التصوير الفني.

المبحث الثاني: بلاغة التفصيل والإيضاح بأساليب الإطناب.

المبحث الثالث: بلاغة التفصيل والإيضاح بأسلوب الحوار.

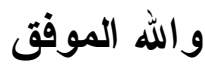

د. محمد بن عبد الرحمن الخراز 


\section{المبحث الأول}

بلاغة التفصيل والإيضاح بأساليب التصوير الفني

توطئة:

طرق البيان المشهورة هي التشبيه، والمجاز، والكناية، والتعريض.

و المقصود بالتشبيه -كما هو مشهور في كتب البلاغة- مقابلة شيء بصورة تشابهه من وجه أو وجوه متعددة، باستخدام أداة التشبيه، وهي الكاف، أو مثل، أو كأن، ونحوها.. وقد يقع التشبيه بغير أداته، مبالغة في إلحاق المشبه بالمشبه به في وجه الشبه.

ومنه (تمثيل الصوت المرتفع بصوت الحمار في القرآن قال تعالى في وصية لقمان لابنه: \}واغضض من صوتك إن أنكر الأصوات لصوت الحمير\{ أي أوحش

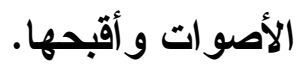

قال القاضي: وفي تمثيل الصوت المرتفع به ثم إخراجه مخرج الاستعارة مبالغة شديدة.

وقال معين الدين الصفوي شبه الرافعين صوتهم بالحمير من غير أداة

التشبيه مبالغة في التفير)

$$
\begin{aligned}
& \text { ' خزانة الأدب، ولب لباب لسان العرب، للبغدادي: I/ } \\
& \text { - VY. - }
\end{aligned}
$$


فلاينا في التثبيه أربعة أركان: مشبه، ومشبه به، وأداة تثبيه، ووجه شبه. ويُعتمد فيه على وجود طرفي التشبيه، و هما المشبه والمشبه به.

و الاستعارة مرجعها إلى التثبيه، فهي تثبيه حُنف أحد طرفيه، إما المشبه، أو المشبه به.. وذلك للمبالغة في إثبات الصورة للمشبه. قال عبد القاهر

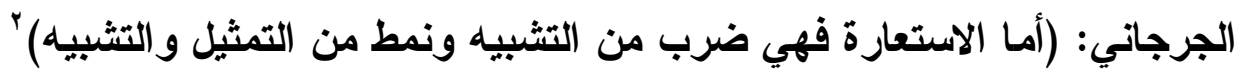
والمثل عبارة عن صورة قصة، أو جزء يعبر عن القصة كلها، نُقل من موضعه الأصلي إلى الموضع الجديد المشابه لذلك الموضع، لوجود علاقة بين

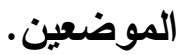

\section{فهذا توضيحات مبسطة لتعريفات التثبيه و الاستعارة والمثل.}

فإنهم عرفوا التثبيه بأنه (إلحاق أدنى الثيئين بأعلاهما في صفة اثتركا في

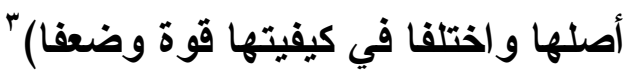

و الاستعارة بأنها: (ذكر الثيء باسم غيره وإثبات ما لغيره له لأجل المبالغة

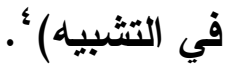

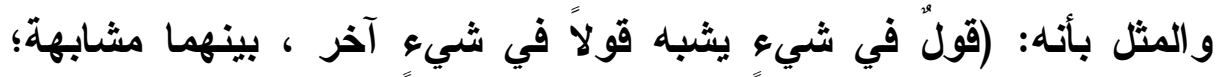

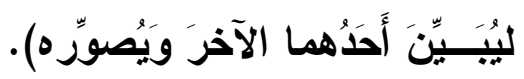

وأما الكناية فهي -كما عند السكاكي في مفتاح العلوم- (ترك التصريح بذكر الثيء إلى ما ذكر ما يلزمه؛ ليُتتقل من المذكور إلى المتروك كما نقول فلان

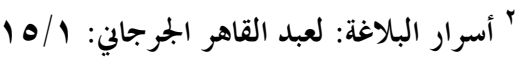

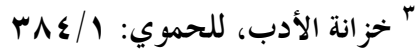

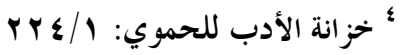


طويل النجاد لينتقل منه على ما هو ملزوم وهو طول القامة [...]سوسي هذا

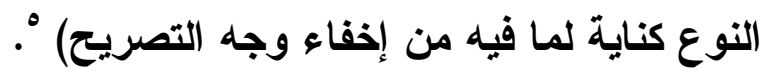

والتعريض هو: المعنى الحاصل عند اللفظ لا به، أي المفهوم من سياق

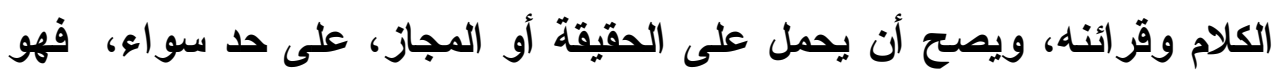

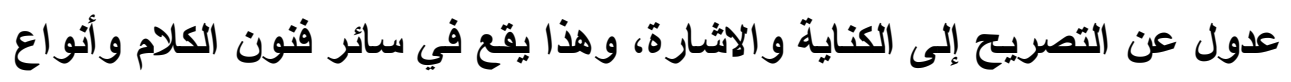
المقاصد.'

\section{أثثر التمثيل و التشبيه في الإقناع والتغييز:}

كل من هذه الأساليب يفيد في تصوير المعاني، وتقريبها من الذهن،

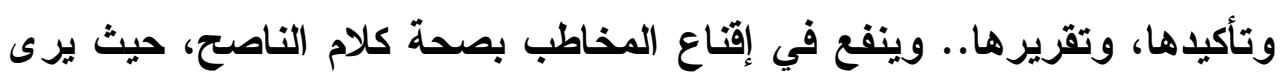
المعاني بمر آة التثبيه، فتبدو له جلية قريبة قوية.

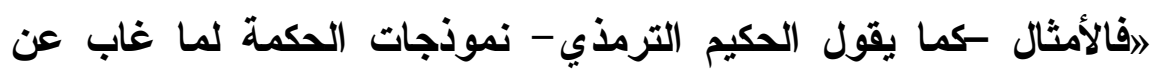
الأسماع والأبصار لتهدي النفوس بما أدركت عيانا.

فمن تدبير الله لعباده أن ضرب لهم الأمثال من أنفسهم لحاجتهم إليها ليعقلوا

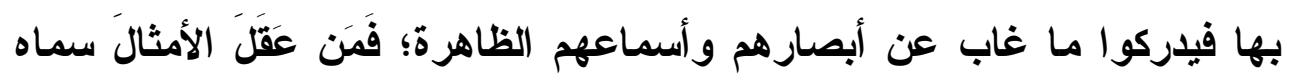

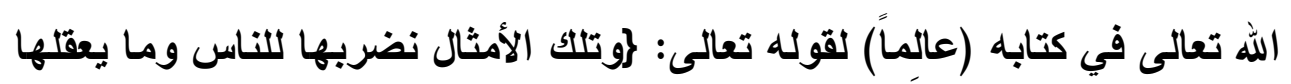

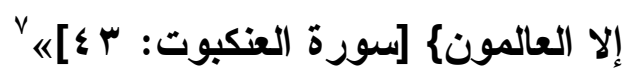

$$
\begin{aligned}
& \text { • مفتاح العلوم، للسكاكي: ب بـ }
\end{aligned}
$$

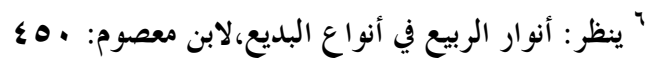

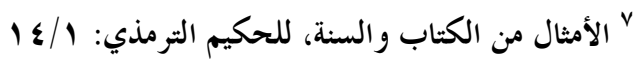


ولذا استتبط أحد العلماء من حديث نبوي جاء على التمثيل بأن فيه إرشادا لضرب الأمثال فى الدين ، و العلم ، والتعليم.^

من التطبقات الدالة على تأثثير الأمثال والتثبيهات وسائر طق تصوير المعاني:

هذه موعظةٌ لإبر اهيم ابن أدهم وقد وقف على القبور فنادى أصحابه.. و واحدا

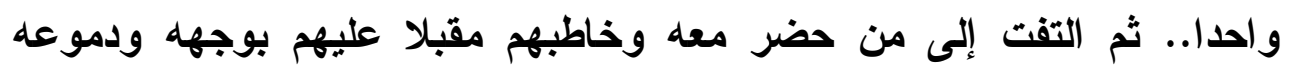
تنحدر كاللؤلؤ الرطب و قال: إخوتي عليكم بالمبادرة و الجد و الاجتهاد سارعوا

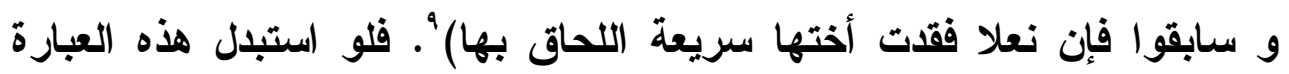
بالقول (فإنكم لا بـ بهم لاحقون)،ونحونها، لما أدت نفس الأثر.

قال الزمخشري في الكثاف: ( ولضرب العرب الأمثال واستحضار العلماء

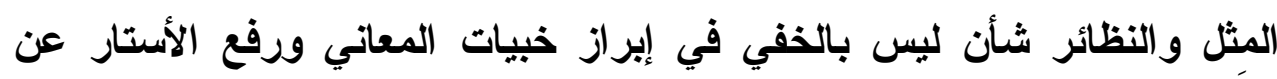
الحقائق حتى تريك المتخيل في صورة المحقق ، والمتوهم في معرض المتيقن ،

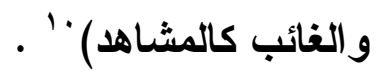

و المثل يطلق (على القول البديع السائر بين الناس الصادر من قائله في حالة

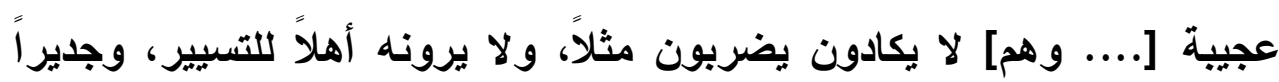

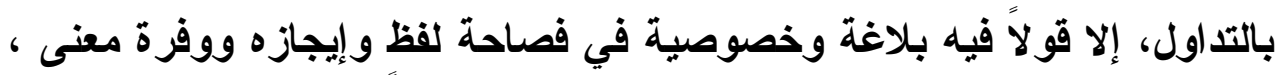

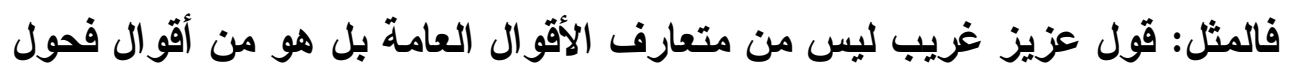

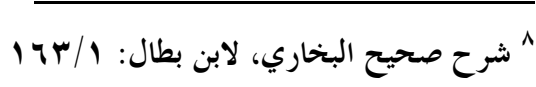

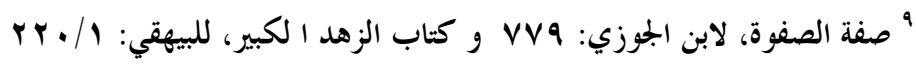

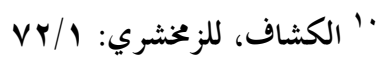


البلاغة فلالك وُصف بالغرابة أي العزة مثل قولهم : "الصيف ضيعت اللبن"

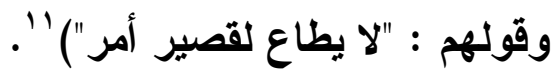

\section{التثبيه وضرب الأمثال في القر آن الكريم:}

وفي القرآن الكريم من التشبيهات والاستعارات والأمثال الثيء الكثير،

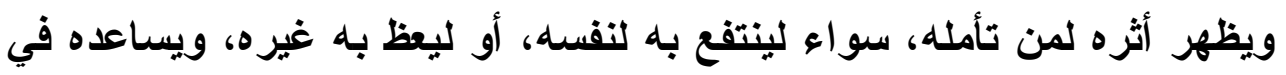

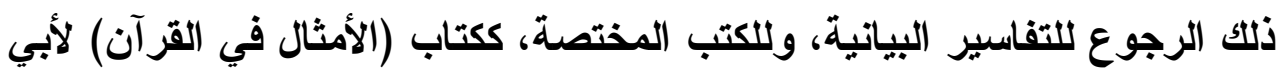
عبد الله الزرعي، وكتثاب (الأمثال من الكتاب و السنة)، للحكيم الترمذي.

قال الزمخشري عن أمثُل القرآن الكريم، وأمثُل الرسل والأبياء: ( ولأمر مًّا أكثر الله تعالى في كتابه المبين أمثاله ، وفثتت في كلام رسول الله وكلام الأبياء والحكماء قال تعالى : روتلكك الأمثال نضربها للناس وما يعقلها إلا العالمون

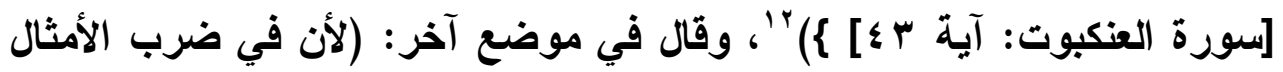

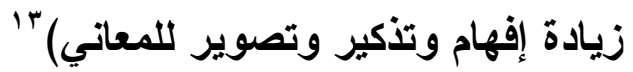

ففي القرآن الكريم أمثال لقلب المؤمن وأعماله، ولقلب الكافر وأعماله، ولأعمال المشركين التي لا تنفعهم، ولأصنامهم كذلك، وللثرك وللتوحيد، ولمن حملوا التوراة ثم لم يحملو ها ولم ينتفعو ا بها.. وغير ذلتك كثير.

قال فخر الدين الرازي: (المقصود من ضرب الأمثال أنها تؤثر في القلوب ما لا يؤثره وصف الثيء في نفسه [...] ألا ترى أن الترغيب إذا وقع في الإيمان

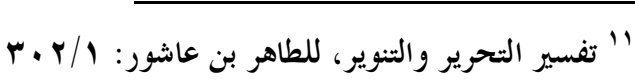

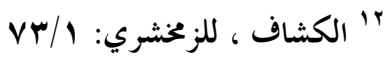

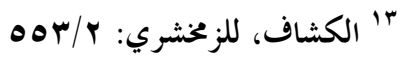


مجرداً عن ضرَبْ مثلٍ له لم يتأكد وقوعُه في القَلب كما يتأكد وقوعُه إذا مُثِّلَ بالنور.

و إذا زُهُّ في الكفر بمجرد الذكر لم يتأكد قُبحه في العقول كما يتأكد إذا مُثِّل

بالظلمة.

و إذا أُخبر بضعف أمرِ من الأمور وضرُب مثَتُهُ بنسج العنكبوت كان ذلك أبلغ

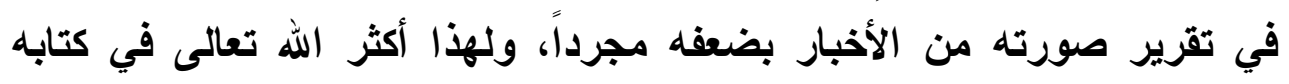

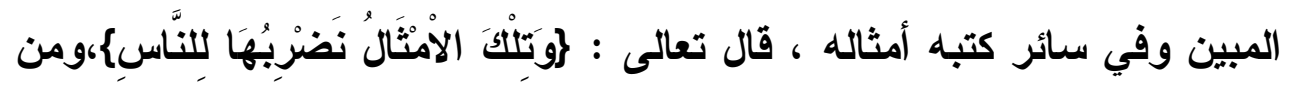
سور الإجيل سورة الأمثال)؛

التثبيه و التمثيل في السنة المطهرة:

وفي السنة النبوية أمثال مضروبة أمرا بالمعروف ونهيا عن المنكر، ففيها

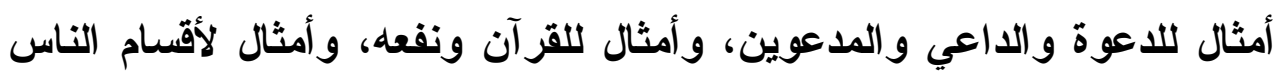

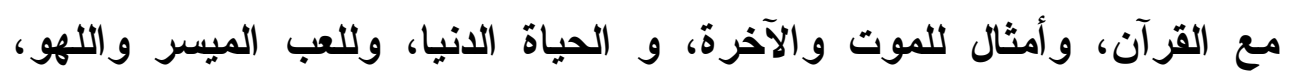

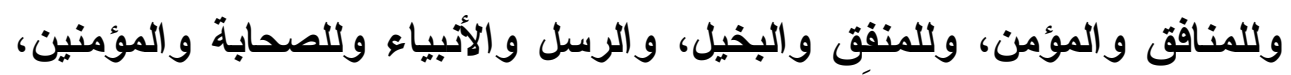
وللصلوات الخمس وما يغفر الله بهن من الخطايا..

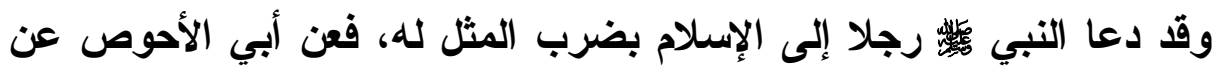

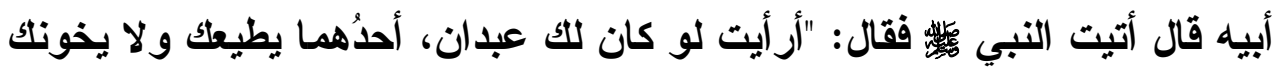

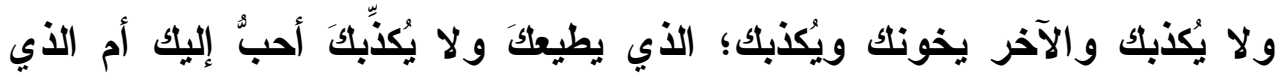

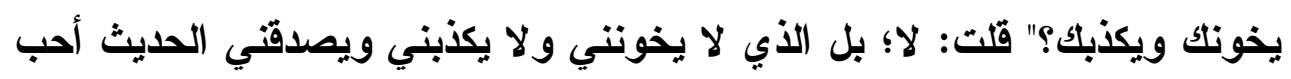

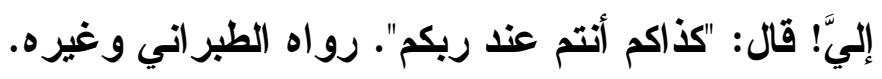

$$
\text { \$' النفسير الكبير: }
$$




\section{التشبيه والتمثل في كلام الحكماء:}

ضرب الأمثال مسلك جليل من مسالكك حكماء الناصحين، فهو يجتنب النفوس إلى الموافقة والمجاراة في المعاني التي يسعى المتكلم لغرسها في نفوس المنصوحين.. قال الحكيم الترمذي: (ولم يزل الحكماء يضربون الأمثال)

وقت شاعت العناية بضرب الأمثال بين أهل الوعظ والتربية، والأمر بالمعروف والنهي عن المنكر، حتى عُرف بها بعضهم، كابي مسلم الخولاني"'، الأي وُصف بأنه (صاحب أمثال)، وقد حكى أصحاب السير عديدا من أمثاله الرائعة، ذات التأثير البين في المخاطبين، ومن ذلك أنه في يوم من أيامه طلب قوما لا يذكرون الانيا في مجلسهم ذلك اليوم؛ ليجلس إليهم، فأبصر حلقة في المسجد فظن أن فيهم مراده، فأقبل عليهم، فإذا هم في أمر الانيا، فقزع لذلك، ثم هُ قال لهم: (سبحان الله! هل تدرون يا هؤلاء ما مثلي ومثلكم؟ كمثل رجل أصابه مطر غزير وابل، فالتقت فإذا هو بمصراعين عظيمين فقال: لو دخلت هذا البيت حتى يذهب عني أذى هذا المطر، فذخل فإذا بيت لا سقف لله، فجلست إليكم وأنا أرجو أن تكونوا على خير، على ذكر، فإذا أنتم أصحاب دنيا) 'ا ل.

وكان ضرب الأمثال دأبه، وبلت ذات إقناع وتأثير في المخاطبين، حتى إنها لتقطع عنه الجدل، وتلزم بالحق، كما في رده على رجل قال له حين كبُر ورقة

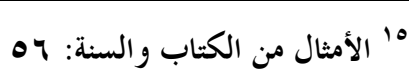

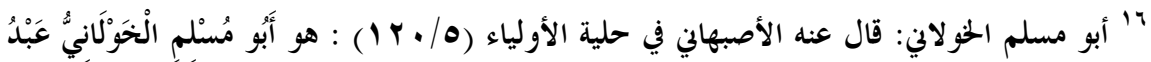

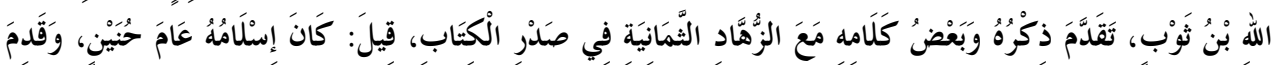

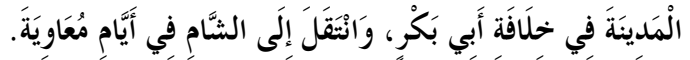

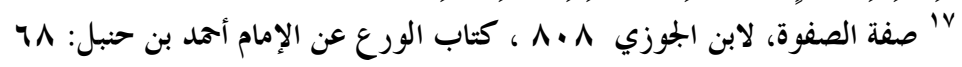


عظمه: لو قصرت عن بعض ما تصنع!؟. فقال: أرأيتم لو أرسلتم الخيل في

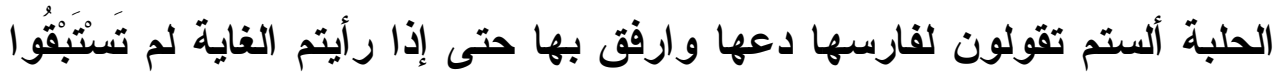

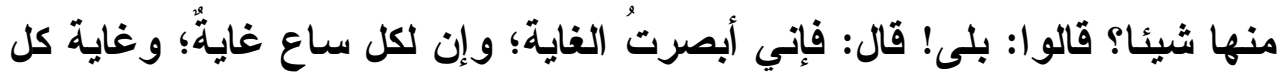

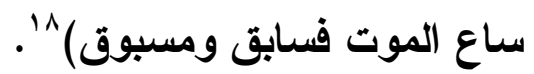
قال ابن أبي الدنيا: (ضرب الأمثال يقرب المعاني البعيدة إلى فهم القاصرين و المتقاعدين عن رتبة أهل البصائر والمتميزين؛كما ضرب الله تعالى أقل الأثشياء مثّلا لنوره في قوله تعالى \}الله نور السماوات والأرض مثل نوره

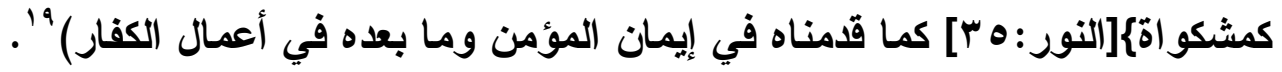

قالت نورة بن محمد السعيد: من أبرز الثواهد على ضربه للأمثلة -تعني الثيخ ابن عثيمين رحمه الله- وتقريبه للمعاني ماحلث له مع والدي -رحمهما الله- حيث كان لاى والدي يرحمه الله بيت زائد عن حاجته ورغب إيقافه بعد موته، واستشار الثيخ هل يفعل أم يتصدق به في حياته؟ فقال له الثيخ: إذا لإ

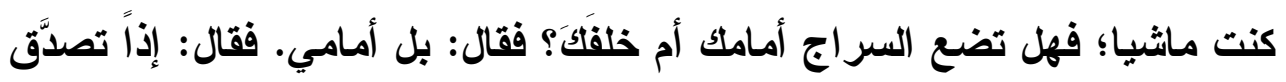
الآن. •

\section{التمثل و المثل العملي التطبيقي:}

وكما يكون المثل قوليا، كما في النصوص السابقة، فقد يكون عمليا، ويقصد

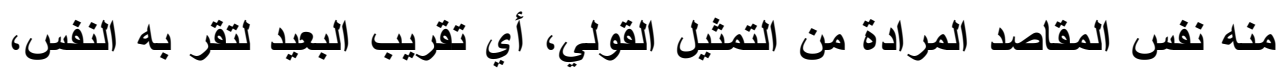
وتوضيح الذفي حتى يكون كالمعاين الظاهر، وتقرير المغنى لتستقر به النفس النس

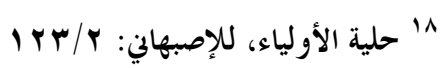

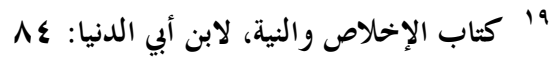

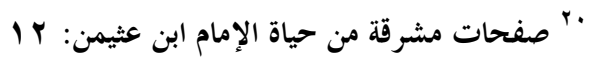


وينشرح به الصدر، وتحسين المعروف لتتحرك له القلوب وتثرئب إليه النفوس، وتقبيح المنكر لتنكسر عنه الشهوة وتسمو عنه الهمة...

ومن التمثيل العملي عن عبد الله بن مسعود ونائه أنه خطا مستقيما ، وخط

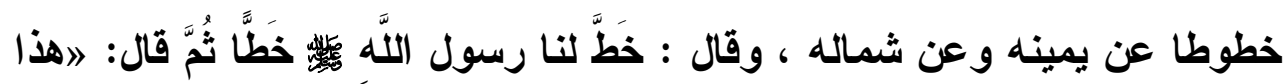

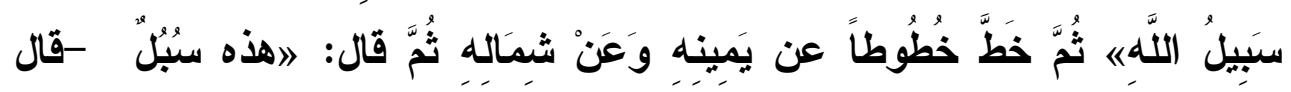

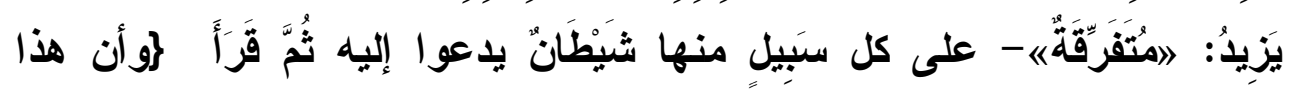

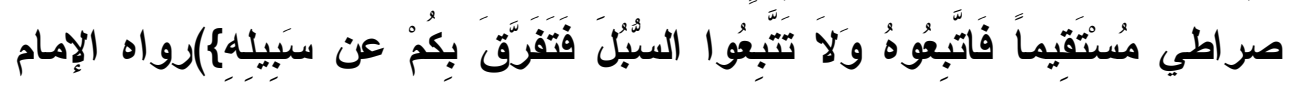
أحمد.

ومن روائع التمثيل العملي أن رجلا جاء إلى الثيخ عبد الرحمن السعدي(ت V V I V اهـ)، رحمه الله وأنكر عنده استعمال المايكروفون في الصلاة

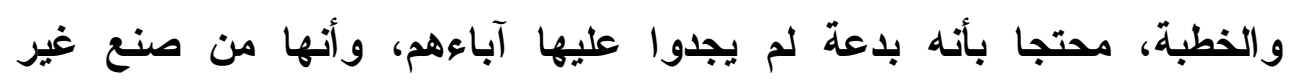
(المسلمين، ولا حاجة لنا بها!!!

وكان على عيني الرجل نظارة، فقام الثيخ فخلعها من عيني الرجل، وسأله: هل ترى بوضوح؟ فقال: لا يا شيخ!. فأعادها إلى عينيه مرة أخرى، وقال:

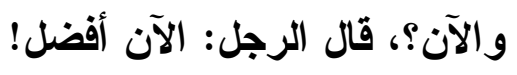

فقال له الشيخ: يا أخي أنت تعرف بأن النظارة تقرب البعيد.. فكنلك مكبر الصوت يقرب الصوت للبعيد، فيسمعه من في آخر المسجد...' لبهي

$$
\begin{aligned}
& \text { "r مو اقف اجتماعية من حياة الثيخ العلامة عبد الرحن بن ناصر السعدي: . . 1 } \\
& \text { - VYA - }
\end{aligned}
$$


وللثيخ مواقت مشابهة في الإقناع بالتمثيل العملي، وكانت ذات أثر فعال في

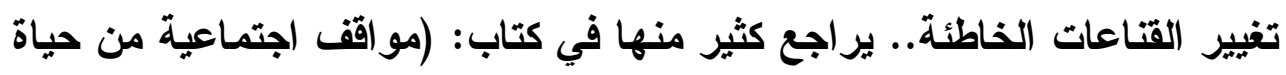
الثيخ العلامة عبد الرحمن بن ناصر السعدي)، وهو من مراجع هذا لئه البحث.

\section{الأمثال و التشيبيهات الوعظية المروية، والمخترعة:}

من الأمثال التي يذكرها المتكلم في نصحه وإرشاده، وأمره ونهيه وتربيته،

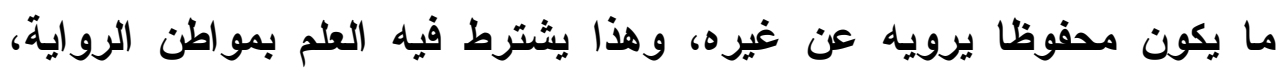
وسرعة البليهة في استحضار المثل الملانم للمقام.

ومنها ما يخترعه المتكلم وييتكره من عند نفسه، فيطبقه على الحال التي

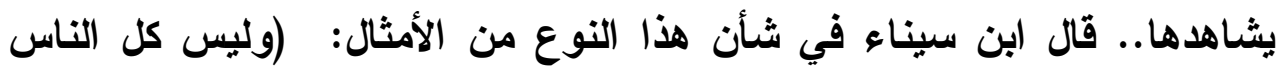

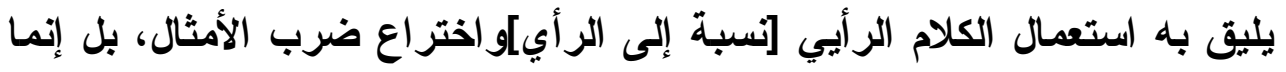

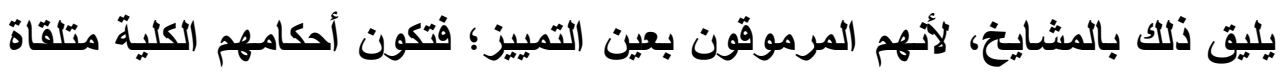

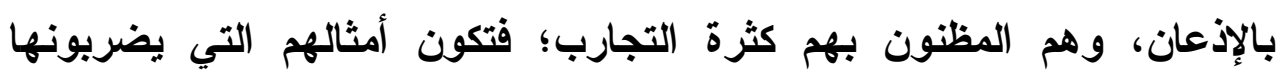
معدودة في الكائن. فإن تكلف الغمر [يعني المغمور غير المعروف بالعلم والفهم] الأي لم يجرب لضرب الأمثال، وإيراد الثواهد من الأحوال، فهو شروع منه فئهي

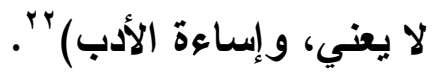

وقال الكلاعي: 》الحكمُ والأمثال على ضربين: فمنهما مارُوي بأثناء الخطبة

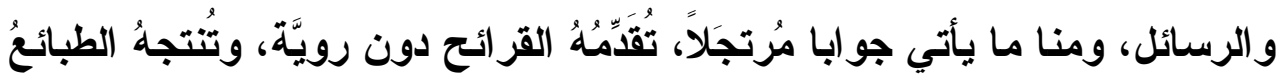
دون كُلفةه.

$$
\begin{aligned}
& \text { rr كتاب المنطق، لأبي علي بن سينا: }
\end{aligned}
$$

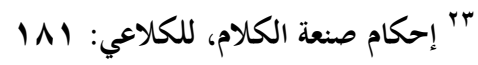


ومن الأمثال المخترعة ما يمكن للأمر بالمعروف والناهي عن المنكر،

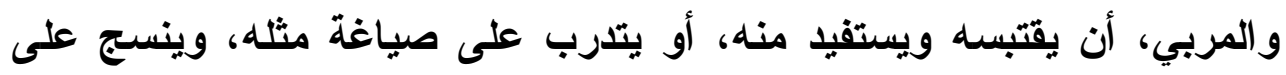

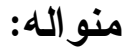

كهذا المثل الجميل الرائع المروي عن صلة بن أثُشَيَم، قال ثُابت البَّاني: كان

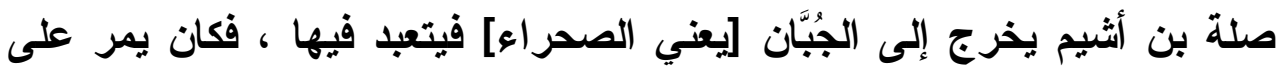
شباب يلهون ويلعبون ، قال : فيقول لهم : أخبروني عن قوم أر ادوا سنَر ا فحادُوا النهار عن الطريق وناموا الليل ، فمتى يقطعون سفرهم ؟ قال : فكان كنلك

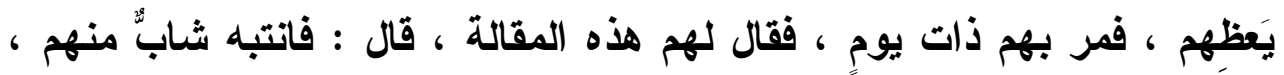

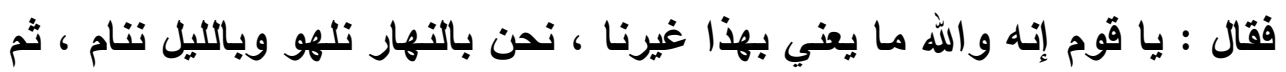

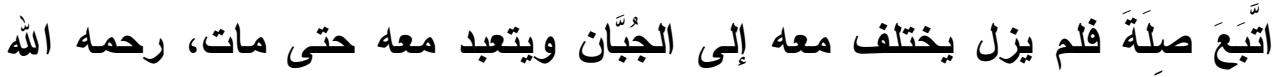
تعالى. ؛

وكهذا المثل المروي عن امرأة من بني إسرائيل وعظت به عالما من

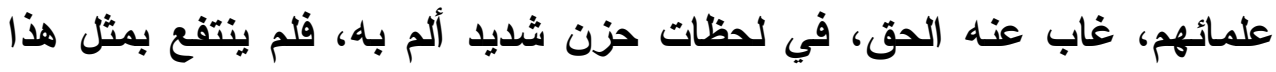

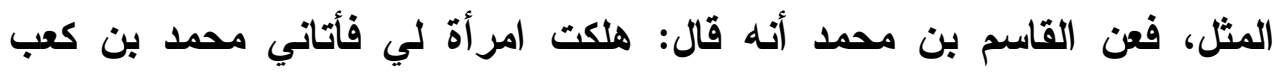

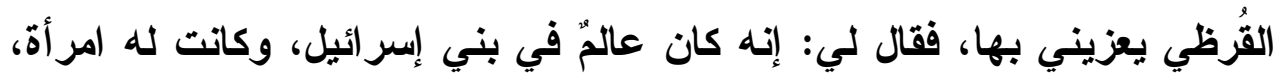

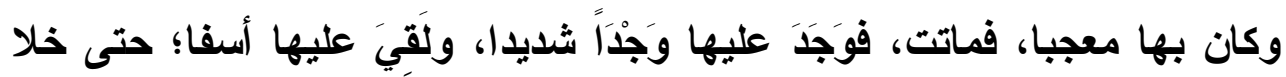

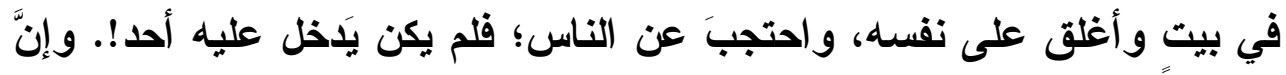

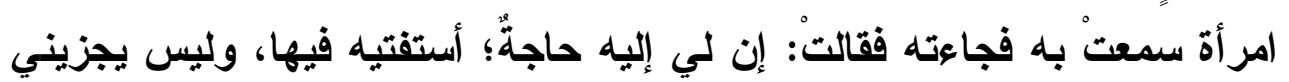
إلا مشافهتُه!

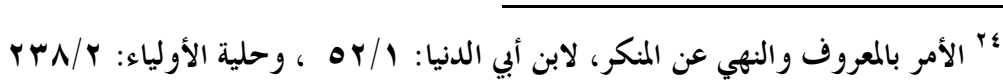

$$
\begin{aligned}
& \text { - VM. - }
\end{aligned}
$$


فذهب الناسُ ولزمتُ بابَه، وقالت: ما لي منه بُدُ! فقال له قائل: إن ها هنا

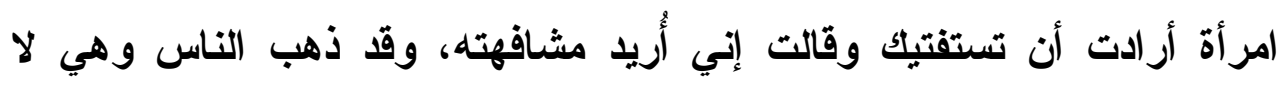
تفارق الباب؟ قال: أئنوا لها.

فرخلت عليه فقالت: إني جئت أستفتيك في أمر؟ قال: وما هو؟، قالت:

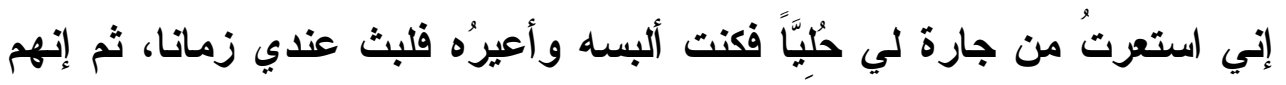

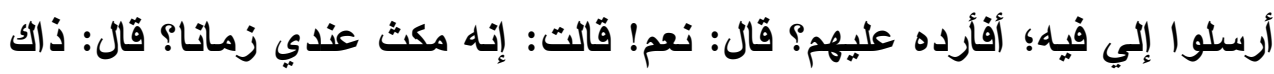

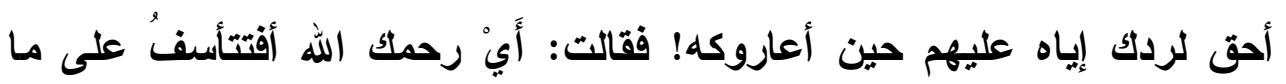
أعاركََّ الله تعالى ثم أخذه وهو أحق به منك؟

فأبصر ما هو فيه ونفعه الله تعالى بقولها. ro 


\section{المبحث الثاني}

\section{بلاغة التفصيل والإيضاح بأساليب الإطناب}

مدخل:

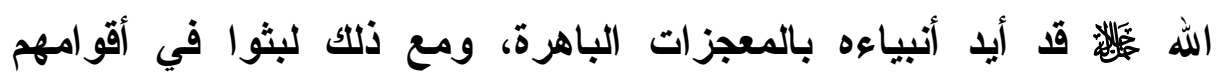
عشرات السينين إلى المئات منها.

وحكى الله عز وجل عن رسله تفاصيل الخطاب مع أقوامهر، حتى ضجروا

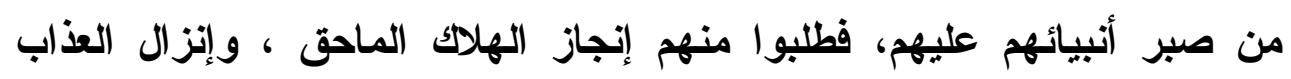

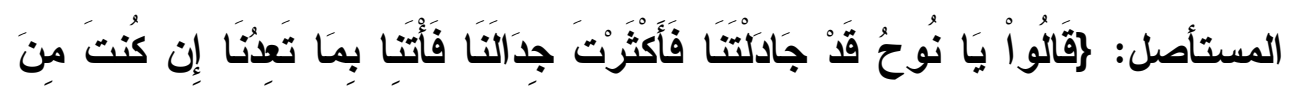

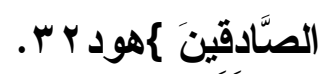

و والتمهل في النصح يلل على سعة الصدر، وهو خلق يحبه الناس في غيرهم، ويتقربون من المتصف به، لا سيما إن بادلهم سعة الصدر عند سماع المداع تفاصيل

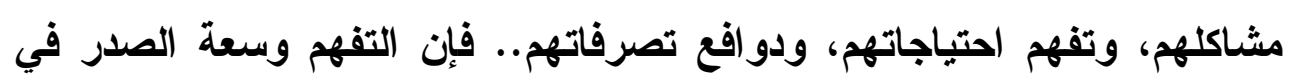

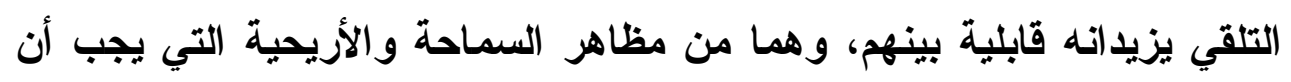

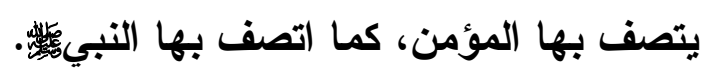

إلا أنه على المحتسب و المربي مراعاة ظروف المخاطبين، فلا يفرض عليهم

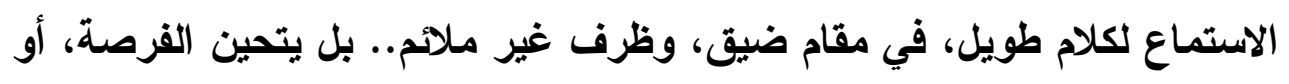
يمهر لها لتو اتيه، فيستفيل منها. 
وقد كان الثيخ ابن باز -مثّلا- إذا أراد الاخول في تفاصيل الاستماع والتكلم

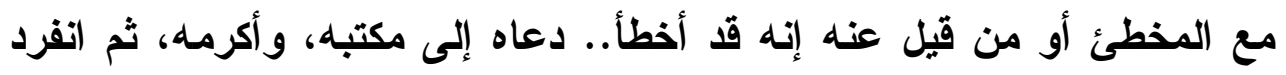

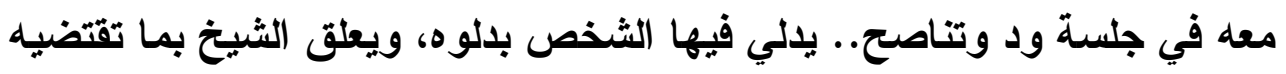

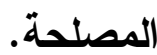

الإطناب والتفصيل أنواع وأساليب، وأثنكال متعددة كثيرة. وله مقامات تستوجبه وتستدعيه، وتحمد فيها عقباه.

وهو بمنزلة الإيجاز إذا المقام استدعاه؛ فلذا قال أبو هلا العسكري:

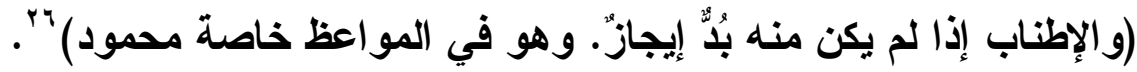

ومن الخطأ في التصور أنه إذا قيل (إن في هذا الكلام إطنابا وتفصيلا)

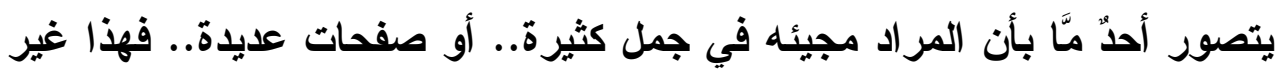

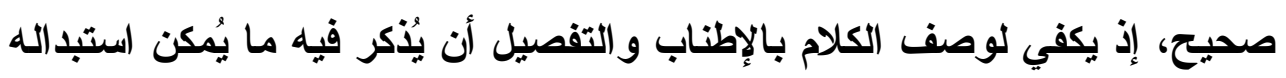
بأقل منه لولا أن المقام استدعى الأطول من الكَلامين.. كما سنرى في تفاصيل

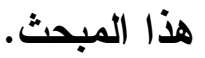

\section{أساليب الإطناب وطرقه البلاغية:}

\section{أولها: الإيضـاح بعد الإبهام:}

ليُرى المغنى في صوتين مختلفتين، وليتمكن في النفس فضل تمكن، أو

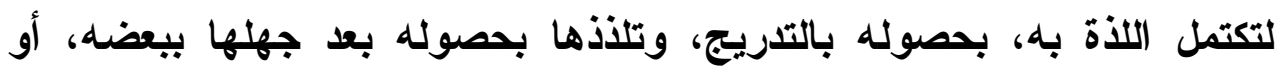

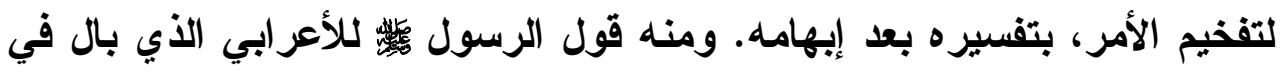

$$
\text { 19\%/ الصناعتين، لأبي هلال العسكري: }
$$




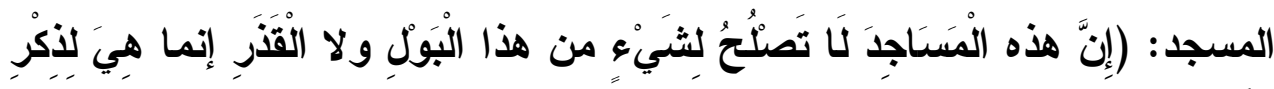

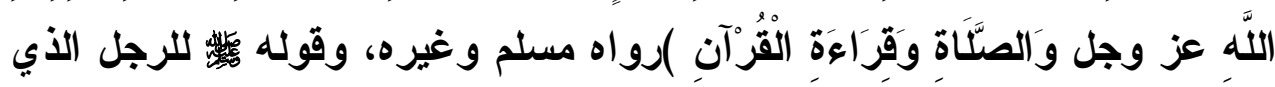

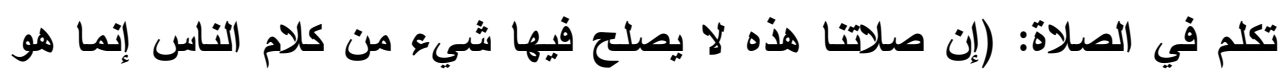

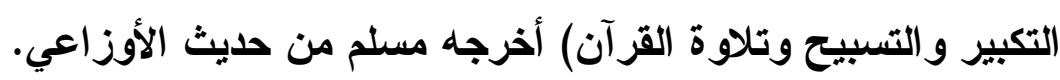

\section{ثانيها: ذكر المخاص بعد العام:}

وذللك للتنبيه على فضل الخاص، حتى كأنه مستقل عن العام..

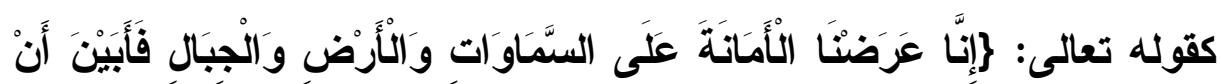

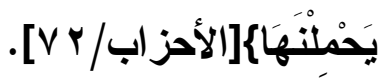

فإن الجبال داظلة في جملة الأرض، لكن لفظ الأرض عام والجبال خاص، وفائدته ههنا تعظيم شأن الأماتة المشار إليه، وتفخيم أمرها.

قال ابن الأثير: (وقد ورد هذا في القرآن الكريم كثير))

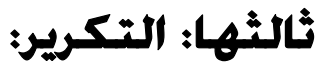

أي تكرير اللفظ، أو الجملة، أو الكلام كله، وذلك لغرض بلاغي، مثل: تأكيا

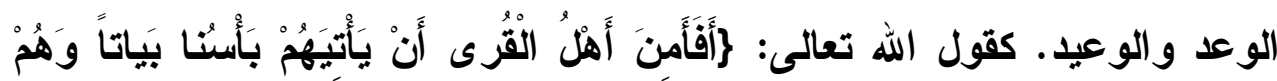

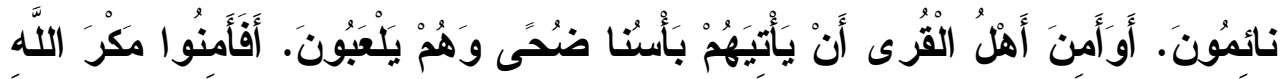

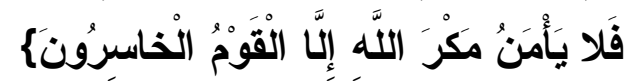

قال أبو هلال العكري عن الإطناب فيها: (فتكرير ما كرّ من الألفاظ هاهنا

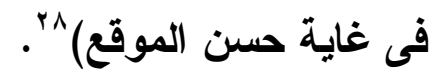

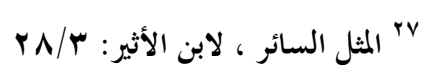




\section{رابعها: (الإيغال):}

وهو ختم الكلام بما يزيده فائدة، وإن كان قد تَمَّ معناه بدونها.

قال أبو هلال العسكري في تعريفه: (وهو أن يستوفى معنى الكلام قبل البلوغ إلى مقطعه؛ ثم يأتى بالمقطع فيزيد معنى آخر يزيد به وضوحا وشرحا وتوكيدا

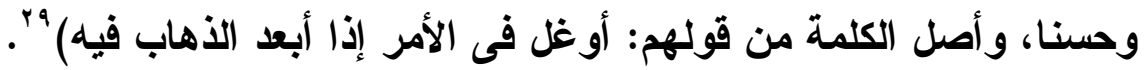

كقول الرسل في دعوة قومهم: (|تبعوا من لا يسأكم أجرا وهم

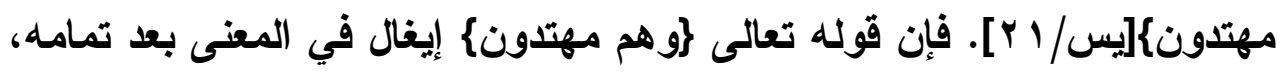
وقا زاد في فائدته.

\section{خامسـها: (التذييل):}

وهو: تعقيب الجملة بجملة تشتمل على معنى الجملة الأولى، ويكون الغرض

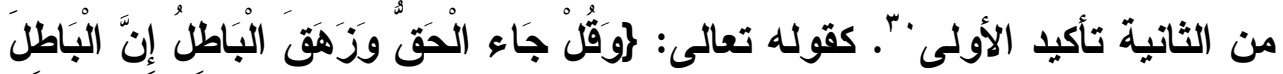

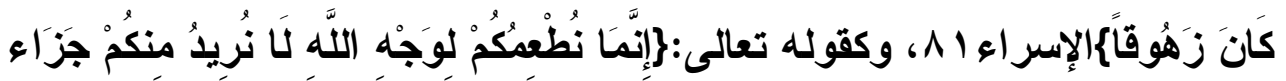

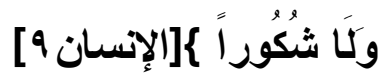

$$
\begin{aligned}
& \text { ^r كتاب الصناعتين، لأبي هلال العسكري: 19 / } 19 \text { / }
\end{aligned}
$$

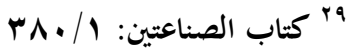

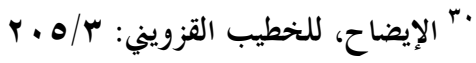




\section{سـادسها: (التكميل):}

ويُسمى -أيضا- الاحتراس، وهو (أن يؤتى في كلام يوهم خلاف المقصود

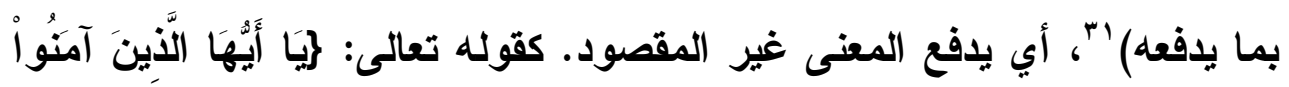

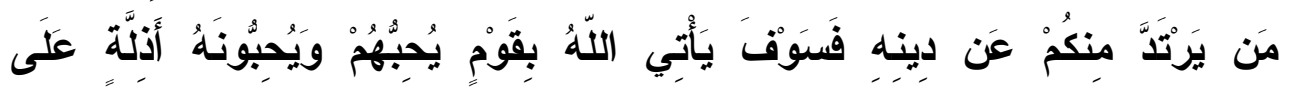

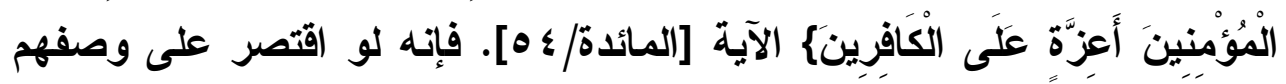

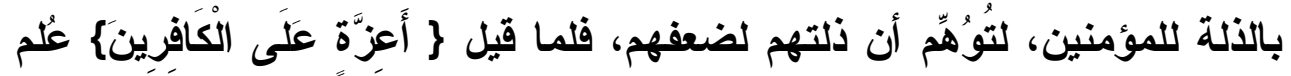
أنها منهم تو اضع، وليس ضعفا.

\section{سابعها: (التتميم):}

وهو: (أن يذكر [المتكلم] المعنى فلا يدع من الأحوال التي تتم بها صحته

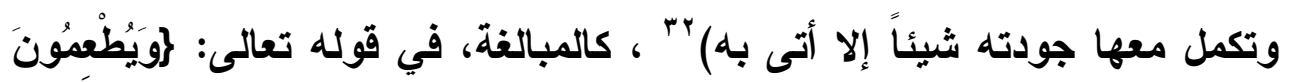

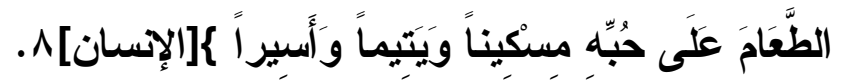

\section{ثامنها: (الاعتراض):}

وهو أن يؤتى في أثناء الكلام -أو بين كلامين متصلين في المعنى- بجملة أو أكثر ، لا محل لها من الإعراب، لغرض في بلاغي معين.

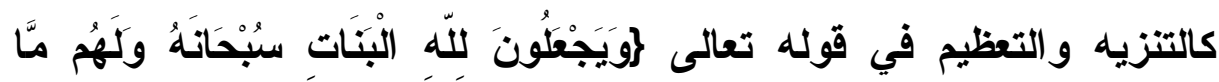

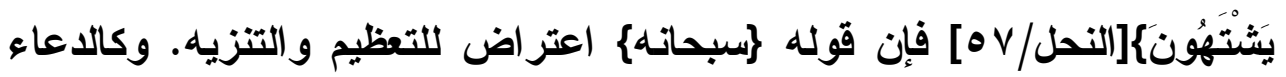

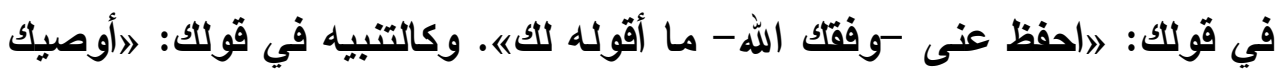

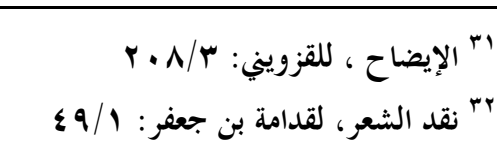


-و الوصية بالخير قد أمر بها الإسلام- أن تحافظ على الصلاةه) . وتخصيص أحد

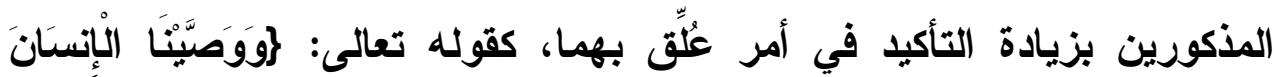

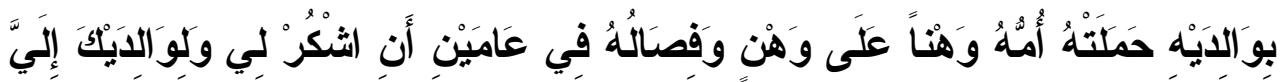
الْمَصيرُ \{[لقمان/\& 1]، فقد خصص حق الأم بزيادة تأكيد فوق حق الأب، عن

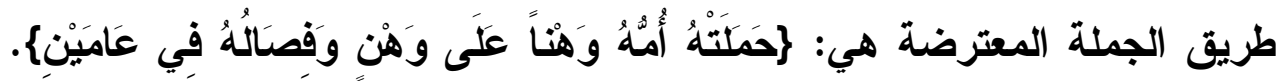
وكالتتبيه على أمر ذو أهمية وتميز، كقولك: ايبقى المسلم عزيزا على كل حال -فعزته من الله وبالله - والكافر ذليلا..«

ووجه حسن الاعتراض وبلاغته أن فيه حسن الإفادة بكلام لم يتوقعه السامع، فيكونه مثله مثل الهاية و الفائدة تأتيك من حيث لا ترتقبها. تاسعرها: (الاسـتطراد) :

ويستفيا منه الناصح بإضافة معلومة لم يتوقعها السامع، لكن يكون في الكلام ما يؤدي إليها ويمهر لها، وكأنها هلية للسامع، كما يناسب في التهيئة والتلطيف لبيئة التربية والأمر والنهي.. كما في قصة معاذ بن جبل رضي الله

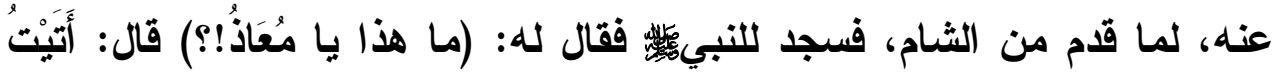

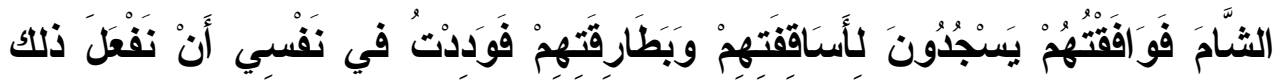

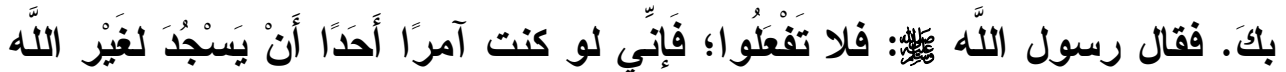

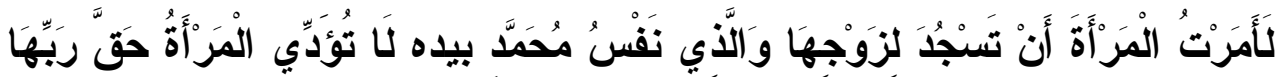

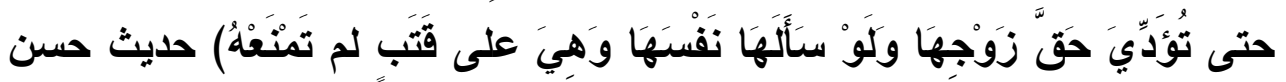
صحيح، رواه ابن ماجة.

فإن النبي صلى الله عليه وسلم لم يقتصر على مجرد نهي معاذ، بل استطرد بفائدة متصلة حاتت لها مناسبة؛ فاستطرد إليها، وهي بيان عظم حق الزوج. 
مقامات الأطناب و التفصيل في أساليب التريية والتوجيه:

المقام الأول: أن يكون الموضوع فقهيا، أو خلافيا، يحتاج لبيان الأدلة المقتعة، لاسيما إن كان المخاطب ذا علم أو صاحب جل .ـ أو لايه شبهة وحيرة في الحكم، فيحسن التفصيل له.

المقام الثاني: أن تكون المعصية أو الخطأ ذا جذور ممتدة عند المخاطب، أو المخاطبين، أو في المجتمع كله، أو معظمه، فيحتاج علاجها لطول البال والنفس، وسعة الصدر، وما يلزم لذلك من تفصيل الخطاب، وتبيين المعاني وكثفها وإيضاح تفاصيلها، بشتى أنواع التغيير، والتفصيل؛ بالكلام، والقدوة ، والمعاملة الحسنة .. و وغيرها.

كما اتسع الرسول كإد في النصح عند معالجة آثار العصبية الجاهلية التي تسللت خفية في موقف عارض إلى نفس أبي ذر رضي الله عنه، وهي آثار معرقة في القدم متأصلة في نفوس الناس، فاحتاج التحذير منها وعلاجها تفصيلا في البيان و إطنابا.

وقد حكى أبو ذر -رضي الله عنه- القصة عن نفسه للْمَعْرُور بن سُويَيْ ،

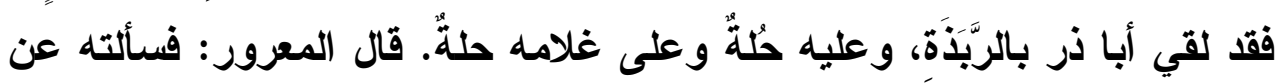

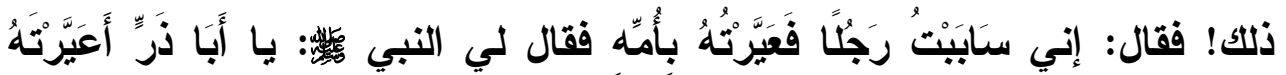

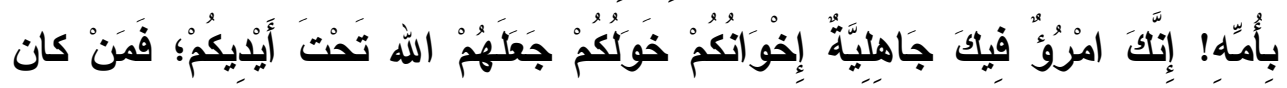

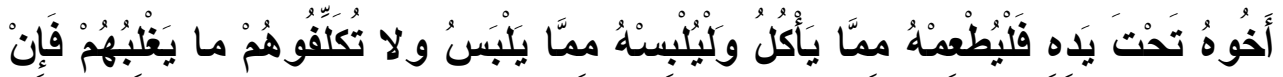

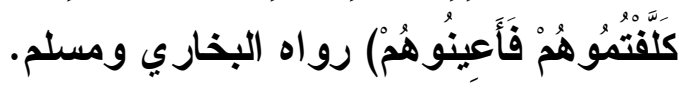


وأما أنه الجاهلية بعد رجوعهم من غزوة، واكتفى

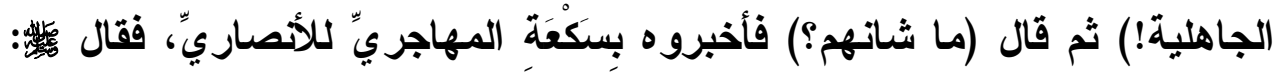

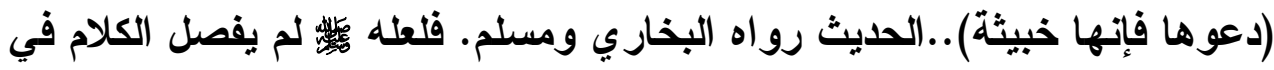

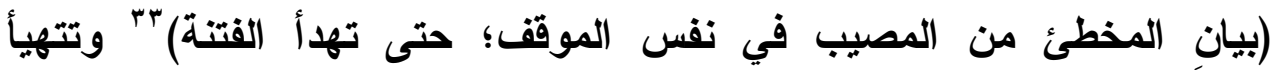
الظروف في المدينة بعد رجوعها: لاستئصال الداء في ظروف أكثر ملاعمة. وهذا لب البلاغة التي هي (مطابقة الكلام لمقتضى الحال)، وتحري أفضل

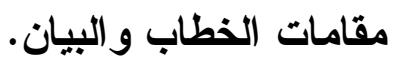

ومن تطبيقات هذا المقام أن الثيخ عبد الرحمن السعدي رحمه الله عذما

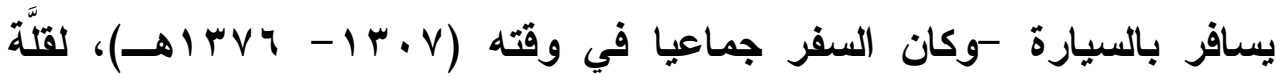
السيارات - كان الناس يختارون له مقدمة السيارة (الغمارة) فكان لا يبقى طويلا

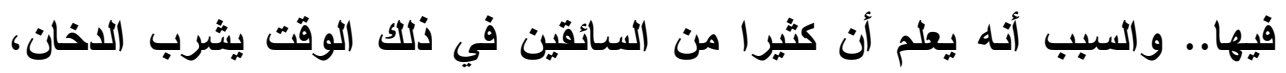

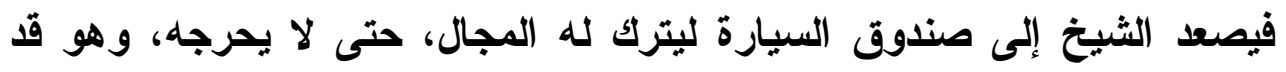

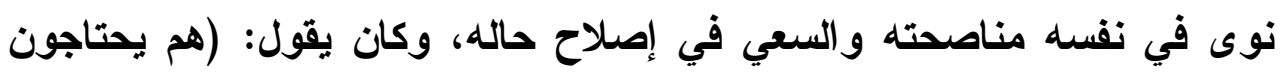

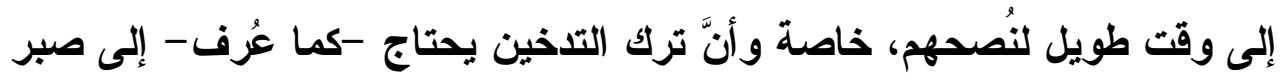

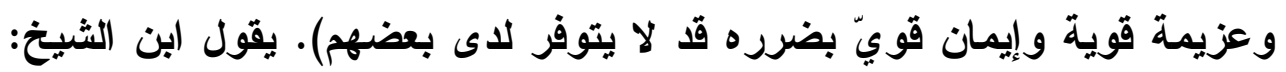

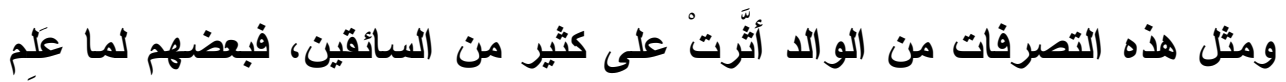

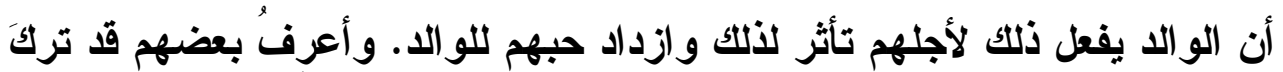
التاخين نهائيا.

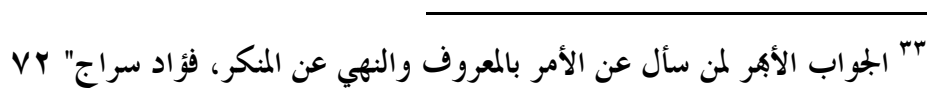

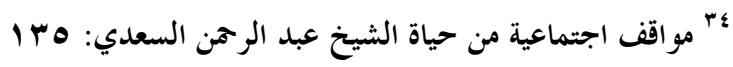

$$
\begin{aligned}
& \text { - VPq - }
\end{aligned}
$$


المقام الثالث: أن يكون مستوى الإدرالك لاى المخاطب أقل مما يتحمله الإيجاز، فيفصل له حتى يبلغ المعنى إلى نفسه أتم إبلاغ.. وإلى ذلك أثشار علماء

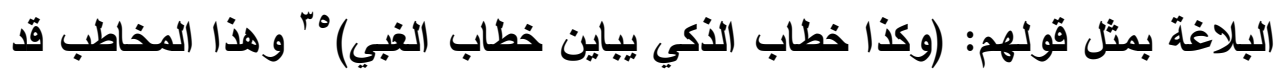
يكون جاهلا، أو غافلا، أو أعجميا، أو جديدا على الإسلام، أو ناشئا في مجتمع غير متثقف بالثقافة الثرعية.. أو طفلا صغير السن.

فأما التفصيل للجاهل فكما في قصة المسيء صلاته، فقد فَصَّل النبيكّة وأطنب في وصف الصلاة التامة ركنا ركنا.. و الحديث مشهور.

وأما التفصيل للأعجمي فقا تتبه إليه الجاحظ في وصفه لبلاغة القرآن المجيد، فقال: (ورأينا اللّه تبارك وتعالى إذا خاطب العربَ والأَعْرَبَ أخرجَ الكلامَ مُخْرَجَ الإثـارة والوحي والحذف و إذا خَاطَبَ بني إسرائيل أو حكَى عنهم جعَه

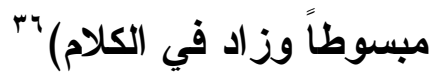

ومن أقرب الأمثلة للإطناب في خطاب بني إسرائيل تلك الآيات المتتابعة في

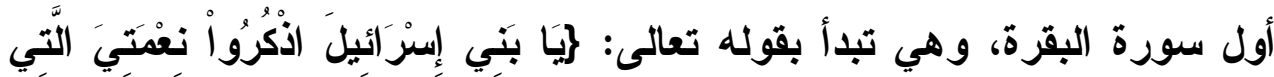

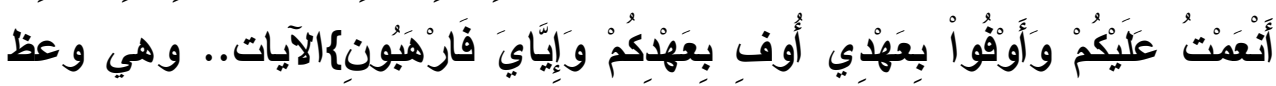
لبني إسرائيل للرجوع عن غيهم، وتذكر نعم الله عليهم المعنوية والحسية؛ وعظا مفصلا على وجوه المعاني تذكير ا، وزجرا، ووعدا، ووعيدا.

وأما التفصيل للطفل الصغير فكما في حديث أبي هريرة هئه قال: أخذ الحسن بن علي رضي الله عنهما تمرة من تمر الصدقة فجعلها في فيه، فقال رسول

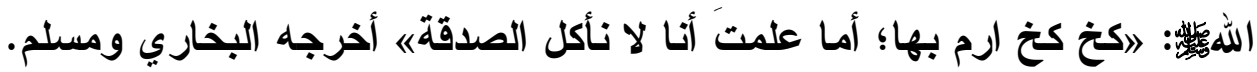

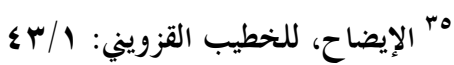

$$
\begin{aligned}
& \text { 4" الحيوان، للجاحظ: / / ع } 9
\end{aligned}
$$




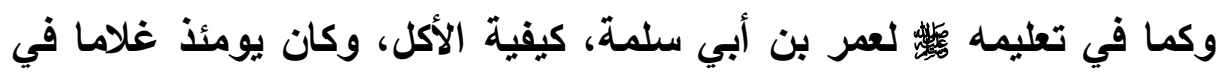

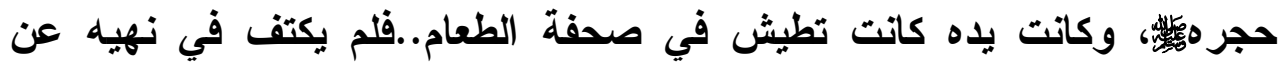
الخطأ الذي وقع فيه بالنهي عنه، بل فصل في تعليمه؛ فقال لها: اياغلام؛ سمٍ الله، وكل بيمنك، وكل مما يليكه متفق عليه.

المقام الرابع: عند السعي في إصلاح ذات البين واستلال سخائم النفوس، و أوضارها، وأحقادها الدفينة، فقلك من أهم مقامات التفصيل والإطناب، ولا الا

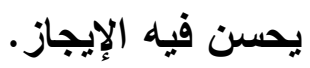

قال الجاحظ: قيل لقيس بن خارجة: ما عندك في حمالات داحس [يعنى

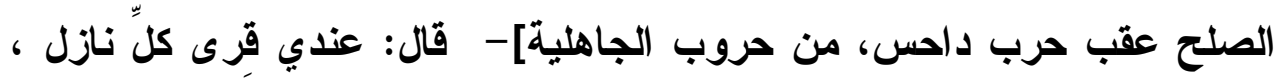

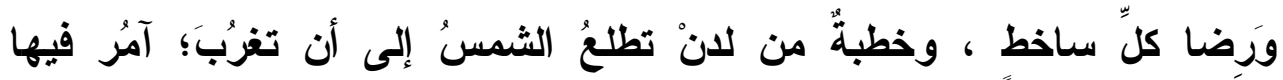

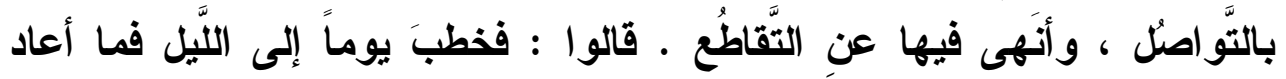

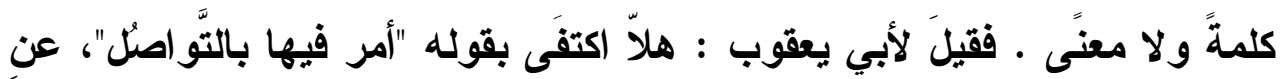

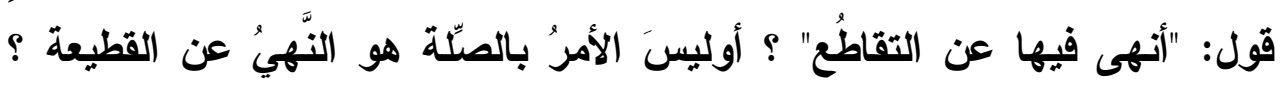

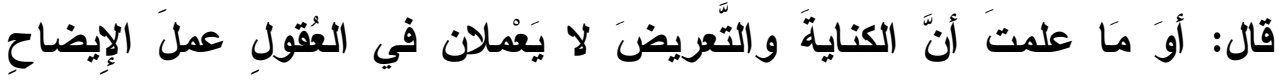

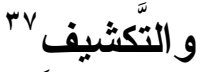

المقام الخامس: عند مخاطبة الثخص القَّق الخائف، أو المتوجس خيفة من

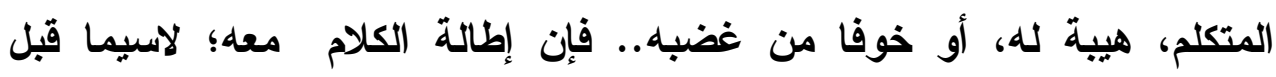
الاخول في تفاصيل أمره ونهيه.. تؤنسه وتزيل وحشته أو تخففها.. ليتهيأ للتقبل 
المقام السادس: أن يكون المخاطب ممن يحبذ سماع كلام هذا الناصح بعينه،

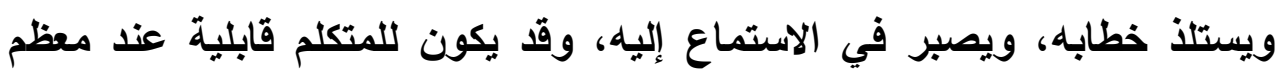
السامعين، -ليس عند سامع واحد- فيتحملون -بل يطلبون- تفاصيله، ويستطيبون الجلوس الطويل أمامه.

ومع ذلك فربما كان من الحكمة الاقتصار على القدر اللازم من الكلام،ولو كان الداعي إليه مثلما ذكرنا، فقد ذكر الإمام البخاري في كتاب العلم، باب من العن

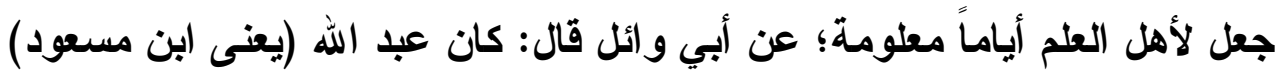

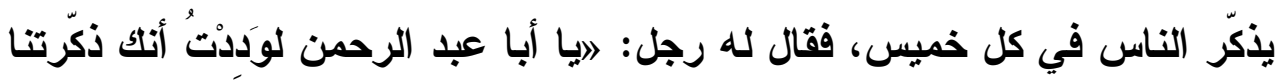

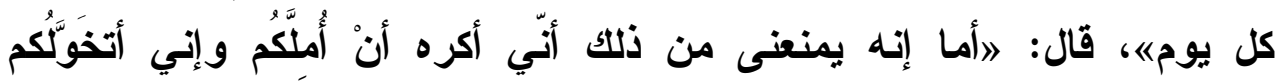
بالموعظة كما كان النبي - صلى الله عليه وآله وسلم - يتخوَّلَّا بها مخافة فئَ السَّآمة عليناه.

المقام السابع: في خطاب المنكر والمتردد.. كما في تفصيل الأمر والنهي لأصحاب القرية التي جاءها المرسلون، فقد فصل لهم الرسل بعد تكذييهم لهم في

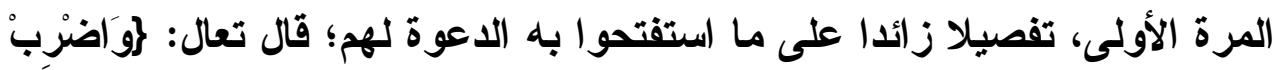

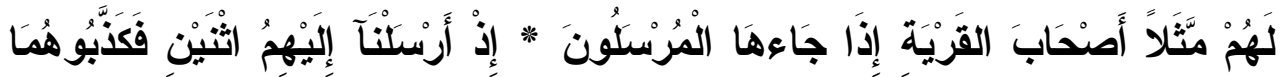

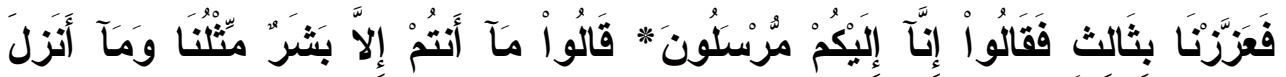

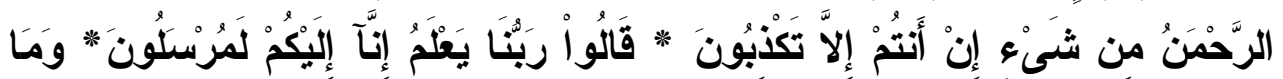

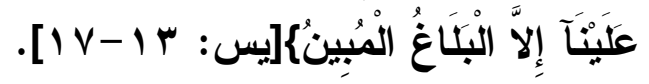

ففي حال كان المخاطب منكر ، وتهيأ المجال للتفصيل، وترجح لاى المتكلم أن المخاطب ينتفع به؛ كانت البلاغة حينئذ فيه. 
وأما التردد فليس جزما بالإنكار، ولكنه حال بين الحالين، ويكون المخاطب

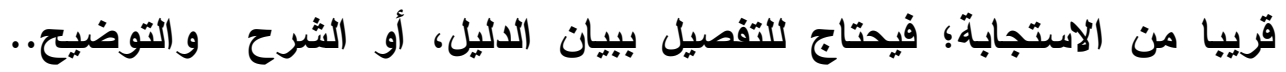

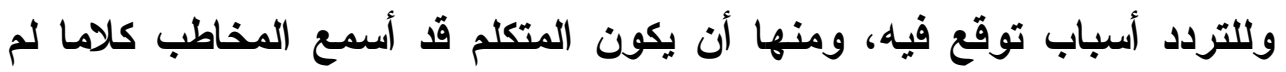
يتوقع مثله، أو أمره بأمر لم يجد الحماس والقتاعة ومنها الكافية لامتثاله، أو نهاه عن شيء لم يتوقع أن يُنهى عنه؛ لجهله بعو اقبه، أو لتعلق نفسه به به تعلقا زائدا.

ومن أمثلة ذلك أن تنهى شخصا عن سماع الغناء، أو امرأة عن التبرج؛ فلا

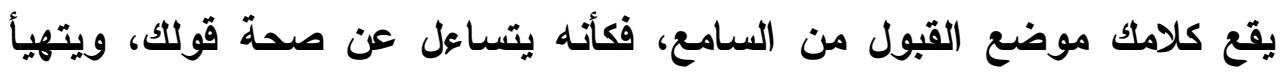

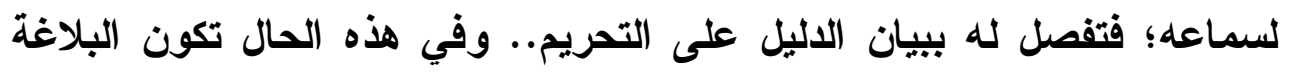

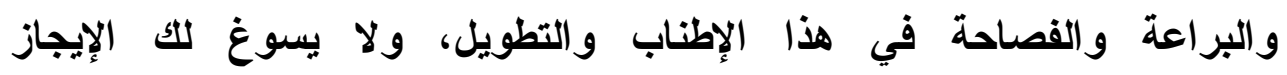

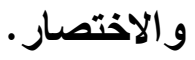

المقام الثامن: في خطاب المعاند والمعرض إعراضا شديدا، فيكون في

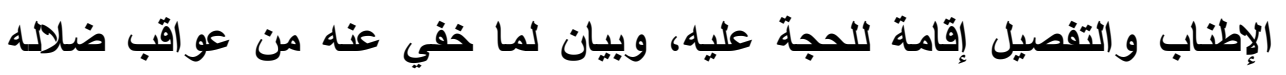

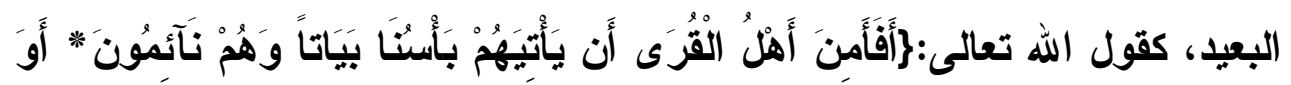

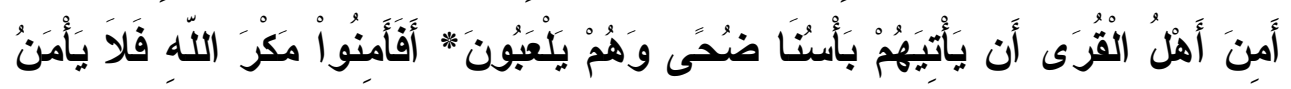

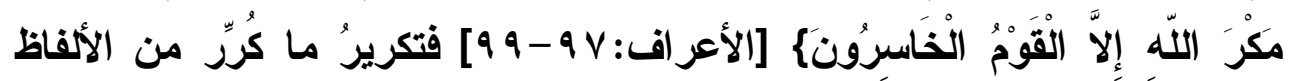

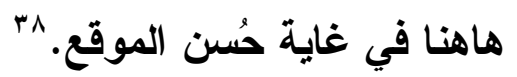

المقام التاسع: عبر عنه أبو هلال العسكري بقوله: (لا شك في أن الكتب الصادرة عن السلاطين في الأمور الجسيمة والفتوح الجليلة وتفخيم النعم الحادثة

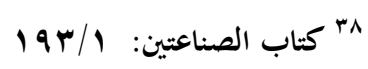


والترغيب في الطاعة والنهى عن المعصية سبيلها أن تكون مشبعة مستقصاة

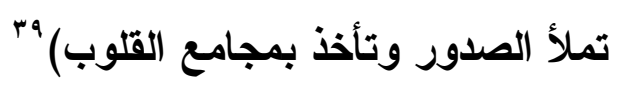

• / /عند إرادة التقرب إلى العاصي بتلطيف العلاقة معه، ومد جسر المودة

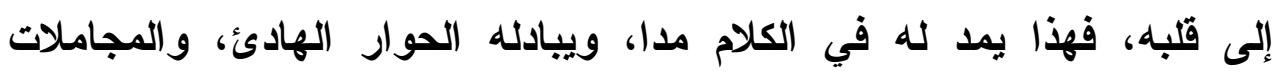

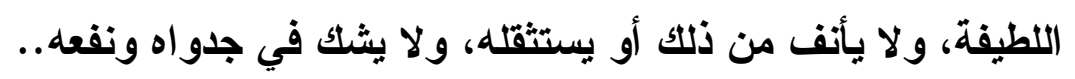
ويلخل في هذا استفتاح الكلام واستهلاله، وطيب المحادثة في أول اللقاء، 


\section{المبحث الثالث \\ بلاغة الثفصيل والإيضاح بأسلوب الحوار}

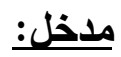

الحوار والنقاش جزء لا يتجزأ من التواصل في مجالات التربية والتوجيه؛ بل إن المحاور غير الجيد، أي الذي لم يتطلم كيف يرد، وكيف يجيب، وكيف يقتع

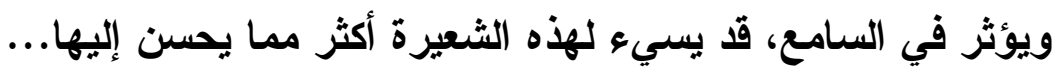

ومن الحوار المقتع ما وقع من عبد الرحمن بن يزيد بن معاوية؛ فقد كان

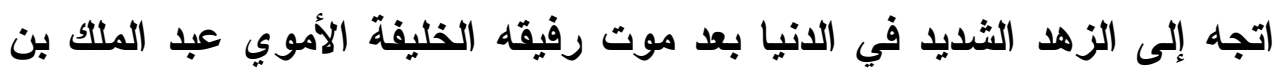

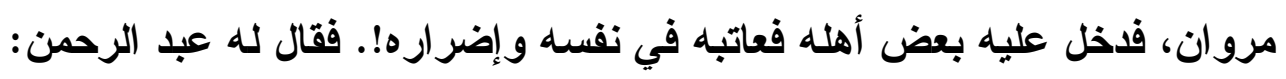

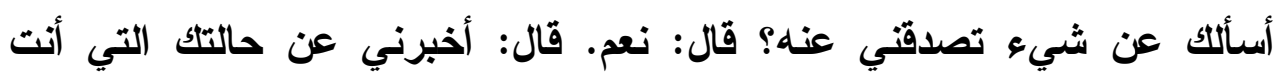

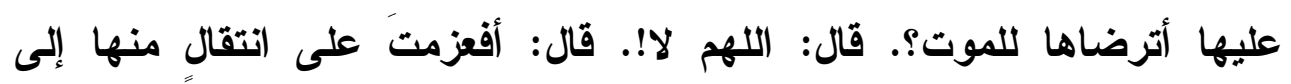

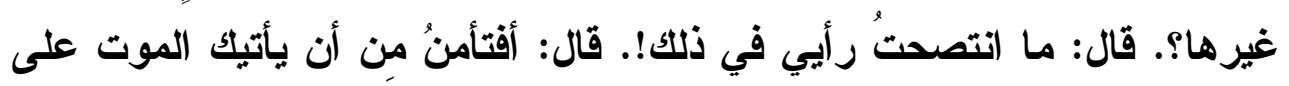

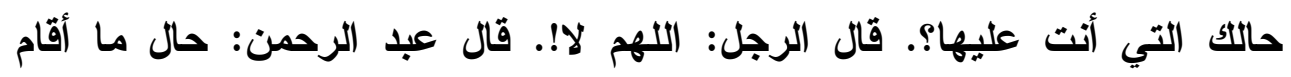
عليها عاقل! ثم انكفأ إلى مصلاه) ؛

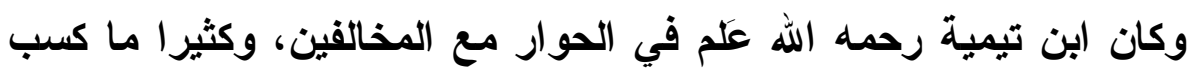

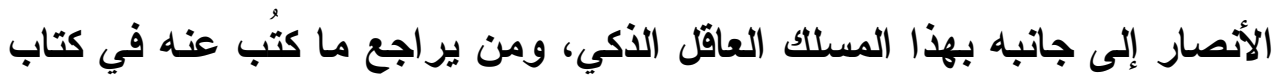

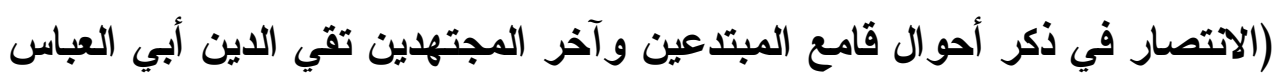

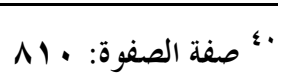




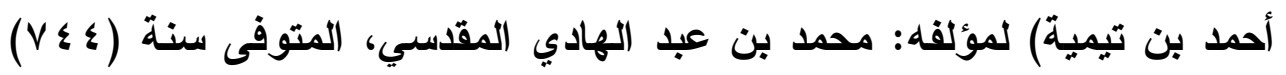
هجرية، يجد فيه بغيته من ألوان الحوار ونتائجها..

وقد رأيت من خلال قراعتي لسيرة شيخ الإسلام ابن تيمية في حواراته أن

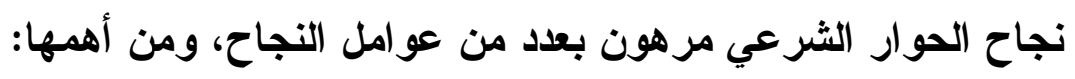
أولا: وجود محاورين أقوياء، نثأوا على عزة النفس، والنزاهة والتجرد، وتربو اعلى العلم والفقه و الزهد، كما هي حال شيخ الإسلام.

ثانيا: وجود سلطة حاكمة تتصر الطرف الذي يظهر الحق على لسانه،

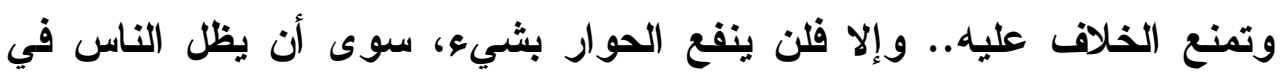

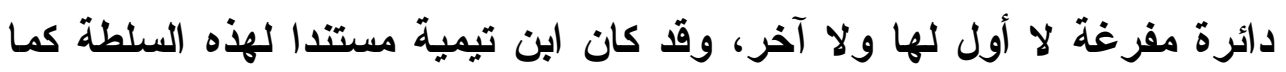

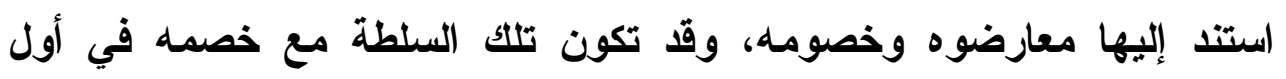

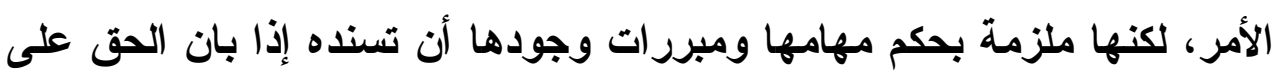
لسانه، و إلا فسوف تسقط شرعيتها _أو تهتز_ ومبررات وجودها. ثالثا: وجود مجتمع يقدر الحوار، ويحترمه، وينادي به، أي وجود ثقافة

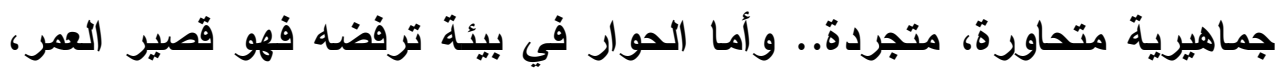
و والتأثير.

\section{رابعا: تأصيل مرجع يلجأ إليه عند الاختلاف.}

وفيما يخص الأمر بالمعروف و النهي عن المنكر، وبيان الحلال والحرام، لا

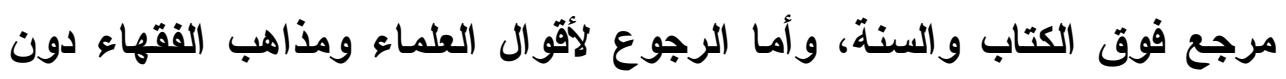

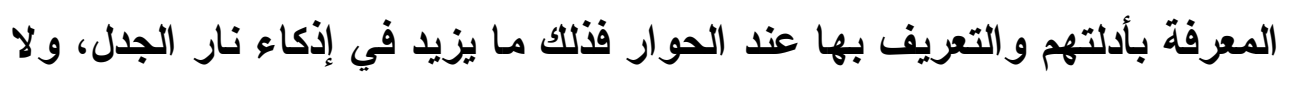

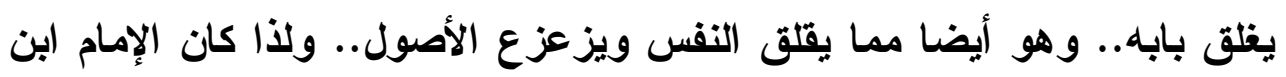


باز رحمه الله لا يرضى بأن يَسب فتواه أو رأيه لمذهب من المذاهب، بل كان

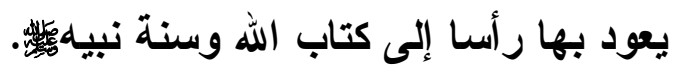

حئثث فهز البكران أنهم نشروا فتوى في مجلة الاعوة ونسبت صيفتها

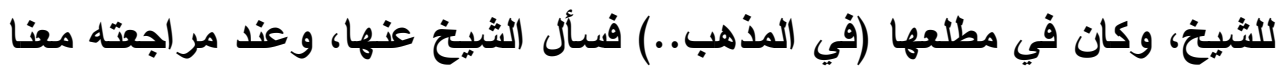

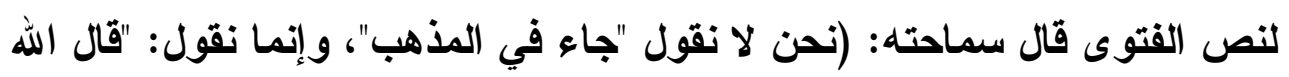

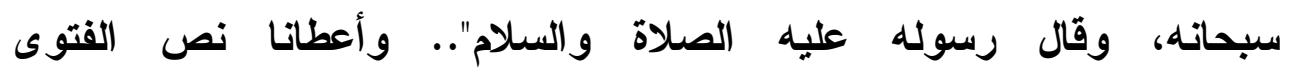

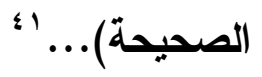

أسلوب الحوار الطويل (المناظرة) وأسلوب الحوار القصير العابر:

الحوار قد يكون طويلا، فيكون في صورة مناظرة، وقد يكون حوار خاطفا وقصير ا.. وكل منهما محتاج لإتقان البلاغة فيه.

وفي علم البلاغة إثـارات متفرقة تنفع في استجلاء بلاغات الحوار اللفظية، وسأتتبعها لاتقاط ما يمكن أن ينتفع به في هذا المجال، وإيضاحه.

ومن الملاحظ أن أسلوب الحوار ربما يختلط فيه الصمت والإضمار مع

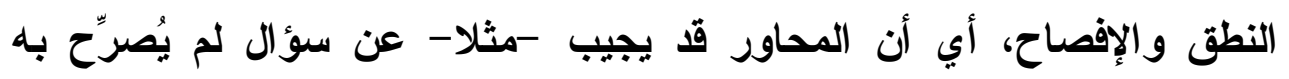

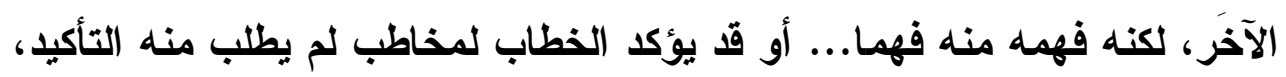

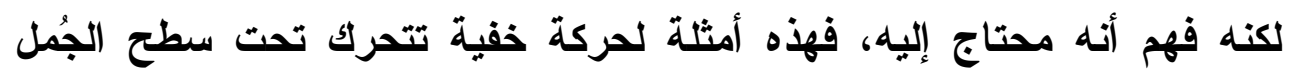

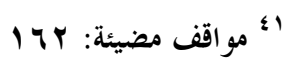


المسموعة، لكن المحاور الجيا يشعر بها، ويلتفت إليها، ويعيها حقها في

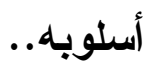

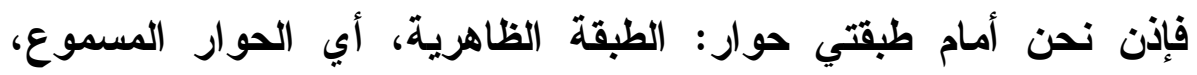
و الطبقة الخفية، وهي المفهومة من حال المخاطب، أو من صمتهـ ـ...

*****

بين الحوار الجدل المشروع و المراء المذموم:

مصطلح (الحوار) قريب -في بعض دلالاته- من معاني الجدال بالتي هي

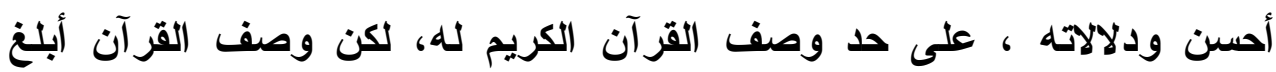
و أكمل وأجمل، من ناحية أن لفظ الحوار يعبر عن التكافؤ في التعامل فقط.. وأما والها

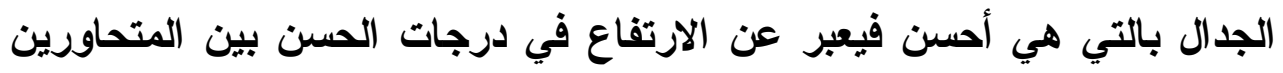

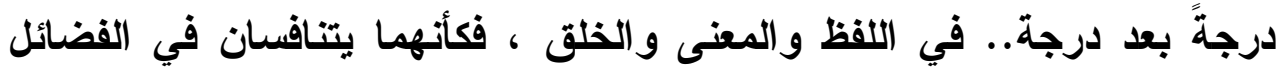
و المعالي بكافة أثكالها.. وليس وراء هذا التعبير القر آني تعبيرا أفضل منهـ..

وأما الجدال المجرد مما وصفه به القرآن، أي الجدل المجرد عن وصف

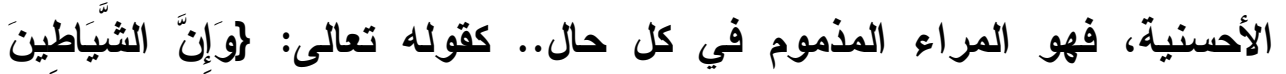

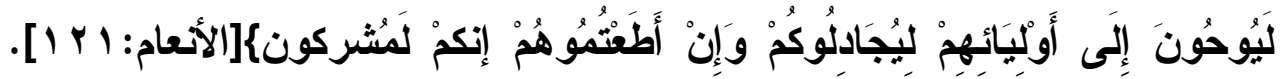
أي: أطعتموهم في تحليل ما حرم الله أو تحريم ما أحل الله..

من علامات تحول الحوار إلى مر اء وجدل مذموم:

حب الظهور، والتعصب وحب الانتصار للنفس، و التعالي، والغرور، و العجب

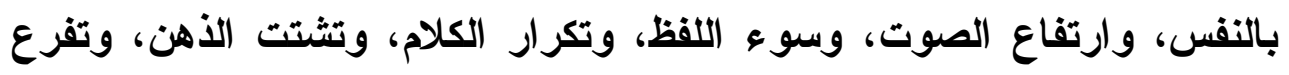


المسائل، والثعور بالإهانة، وغياب الهـف المشترك، والتوتر، ومقاطعة المتكلم، والثماتة به، هي من علامات انحراف الحوار والجدل بالتي هي احسن إلى المراء المذموم، والجدل المستقبح.

وقد كان العلماء الناصحون يهربون من المراء هروبهم من السباع الضاريات، وقد قرأت في سيرة ابن باز رحمه الله، الأي علما في الحوار بالتي هي أحسن، فإذا هو إن رأى الجــل بالتي هو أحسن قد تحول إلى مراء ومماحكة ، تَركَهُ.

حتى اعترف بعض من كان بُعارضه من أهل الجدل باحتر امهم لطريقته، وتأثرهم بها، بل ربما كان تركه للجدل معهم سببا في تركهم لرأيهم المخالف الأي كانوا يستميتون في الدفاع عنه، كما اعترف بذلك أبو عبد الرحمن بن عقيل الظاهري، قال: أتيت سماحته فأفتاني.. وكان قد حُمل إليه عدد من (مجلة الثقافة والقنون)؛ كتبت فيها خمسا وأربعين صفحة مما لا تسر الكتابة عنها، ولا تشرِّف. فصار ينهرني، وكان الثيخ دائما يردد: "ما أعظم مصيبته عند الله!". ثم صار يبرم أطر اف غترته، ويدعو لي، وقد اغرورقت عيناه، فزالت الموجدة من نفسي، وتمزق قلبي حزنا لصدق هذا الإسسان في موعظته، وحرصه على هداية الناس، وطلب حسنى العاقبة لهم، ولو جادلني لكابرتُ في المجادلة، وقد فتح الله قلبي لحسن نيته، ومنذ تلك اللحظة بشهور تقلَّص حب الغناء والطرب من وجداني، وتولدت عندي كراهية الغناء كراهية ما كنت أتصور حدوثها قطة. فسبحان مقلب القلوب) بـ؛

rأ مواقف مضيئة من حياة الإمام ابن باز: · Pr 
وكاتت أعظم وسيلة عند الثيخ في قطع حبل الجدل هي بيان الحق الذي

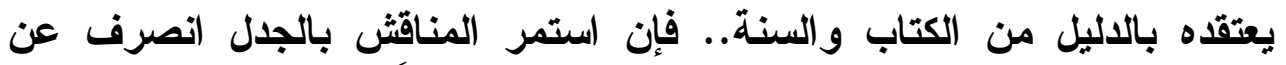

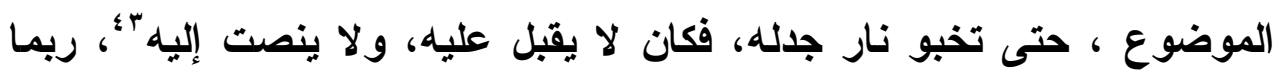

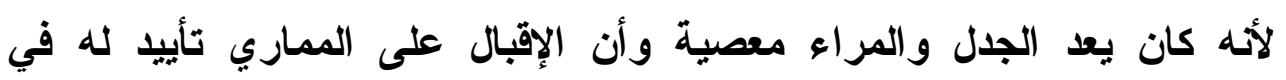

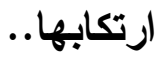

وكان كما وصفه ابن عقيل الظاهري: (لا يحب الجدل و التشقيق الفلسفي)؛ ثم كان الثيخ يردد التسبيح والدعاء والأكره؛ حتى ينقطع المجادل عن جدله، ومن ثم يستأنف الثيخ درسه.

وقد اهتم الدعاة إلى الله بتظلية عبارة الأمر بالمعروف والنهي عن المنكر مما يثبر إلى حظوظ النفس، وما تحقق لهم ذلك إلا بتطهير قلوبهم من تلك الته الحظوظ الدنيوية.. ولذا كان الاتتفاع بكلامهم كبير ا..

وكان الثيخ ابن عثيمين قد اعترض على من مدحه بقصيدة ربط فيها قوة

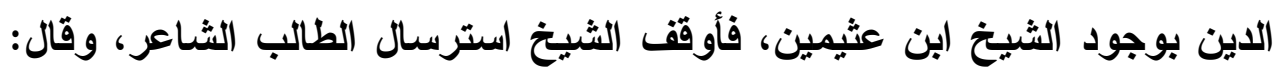

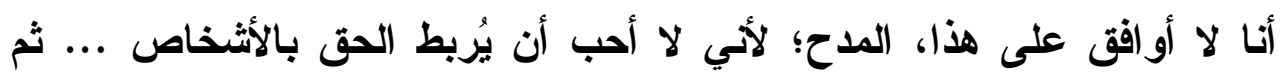

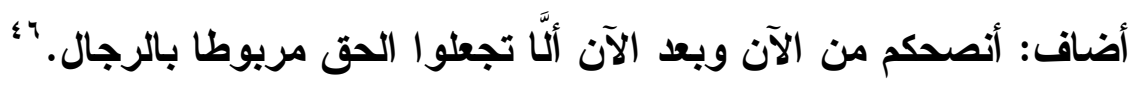

ومن علامات صدق الاحتساب أن لا يقطع العلاقة انتصارا لنفسه ممن لم الم النه

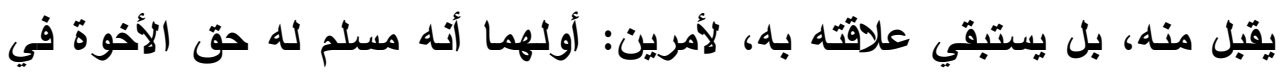

$$
\begin{aligned}
& \text { r" ينظر : مواقف مضيئة من حياة الإمام ابن باز: سبr }
\end{aligned}
$$

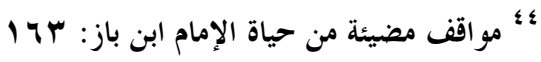

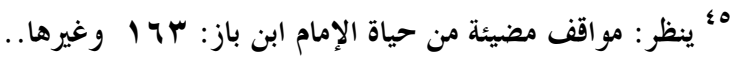

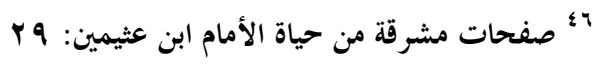


الاين، وثانيهما: أنه قد يعود بعد أن يراجع نفسه ففي الهدوء مساعدة للعاصي

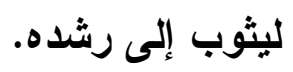

فقد لا يتحقق القبول في أول الكلام معله، لكنه بعد أن تهلأ نفسه ويتجرد

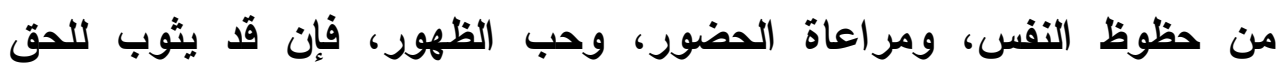
المطلوب.. - المن

يقول عبدالله بن صالح العبيلان: سألت الثيخ ابن باز عن أن كثيرا من

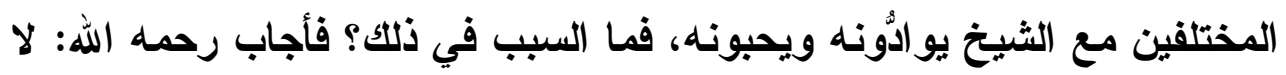

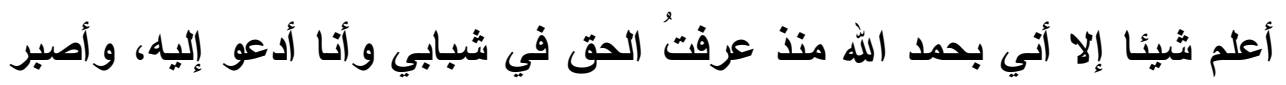

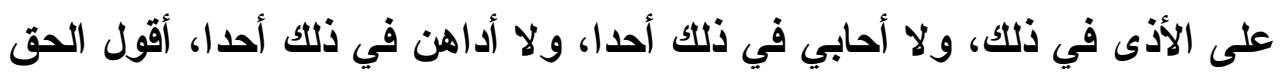

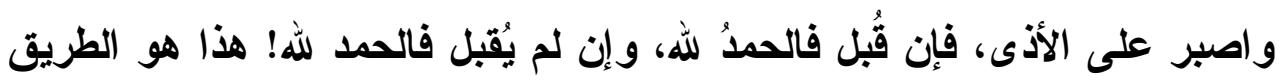
(الذي رسمته لنفسي؛ مشافهة ومكاتبة)....

\section{مهار ات بلاغية في الحوار و المناقثة:}

\section{المهارة الأولى: حسبن الاستماع:}

فإن المخاطب إذا لم يحسن الاستماع لم يقف على المعنى المؤدّيّي إليه

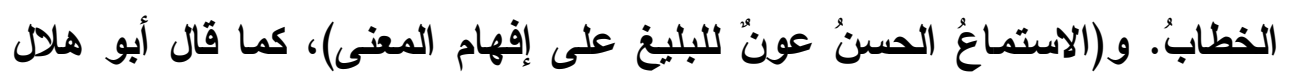

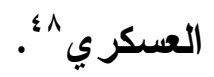

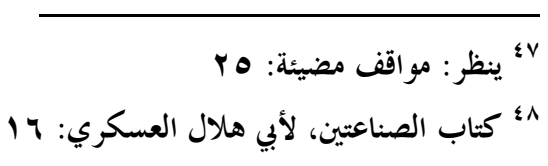


وفي حسن الاستماع عدل، و المحتسب و الناصح في محل القاضي، على ما

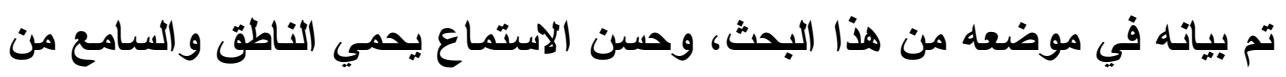
سوء الفهم، وما يترتب عليه من المفاسد.

وفي التذكرة الحمدونية: (تعلّم حسن الاستماع و إمهال المتكلم حتى ينقضي

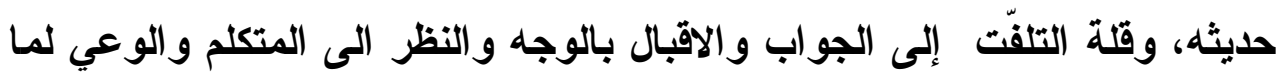

يقول)

\section{المهارة البلاغية الثانية: الإبداع في إثارة الأسئلة والقدرة على الإجابة عليها..}

بعض من أساليب الناصحين تعتمد على ترصدُ انبعاث التساؤلات في نفس فئس السامع، ليأتي الجواب في محله، ويقع موقعه بعد أن تكون النفس قد طلئ تلبته وتطلعت إليه..

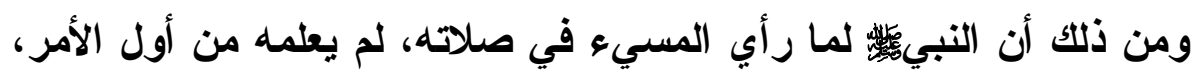

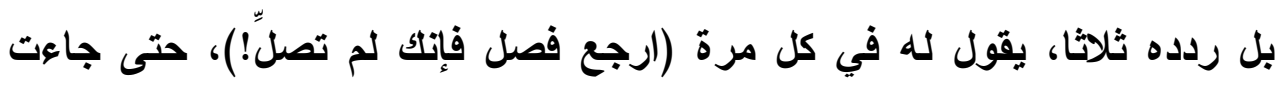

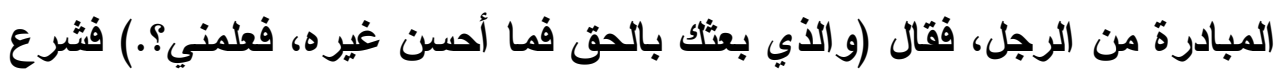

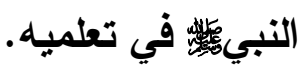

ويتبادر من أساليب البلاغة هنا الفن المسمى (شبه كمال الاتصال)، ومعناه:

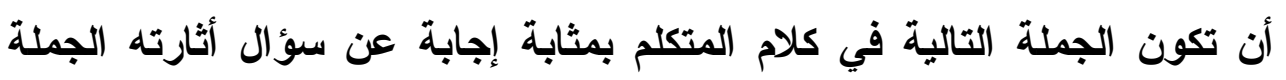

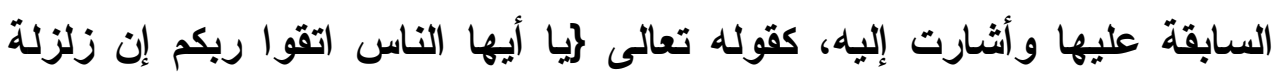

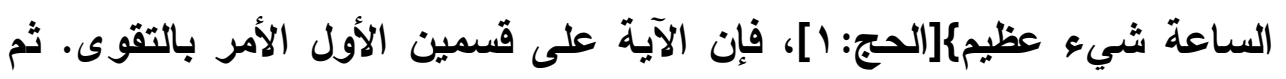

$$
\text { 9؛ التذكرة الحمدونية، لخمد بن حمدون: / }
$$


تعليل هذا الأمر وبيان سببه الداعي إليه، وكأن هذا التعليل وقع إجابة عن سؤال

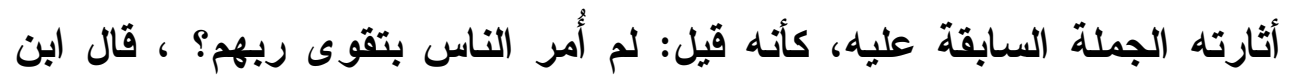
الأثير: (فإن هذا الابتداء مما يوقظ السامعين للإصغاء إليه). •

وهذا هو ماسمي (ثبه كمال الاتصال) وهو من أبحاث باب الفصل

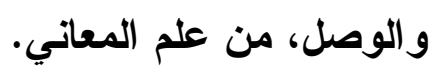

وقد يصرح المحاور بهذا السؤال، فيحاور به علانية، كما في هذه القصة:

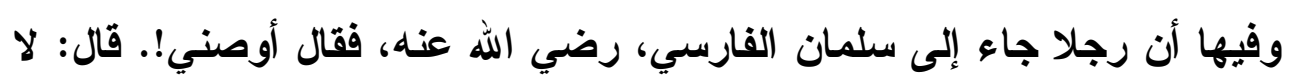

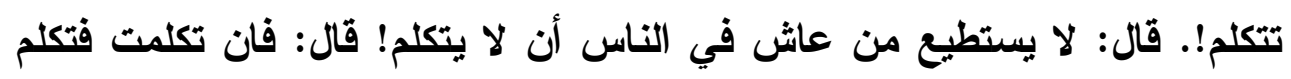

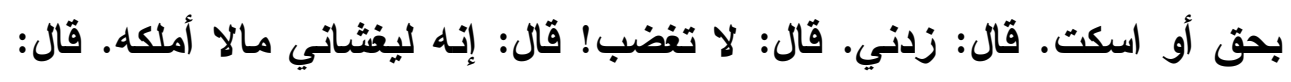

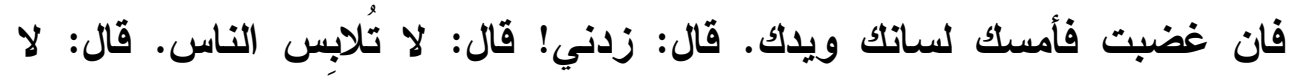

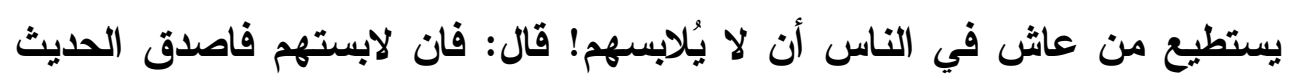

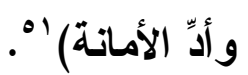

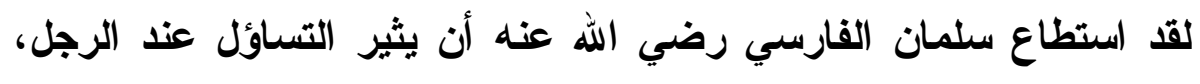

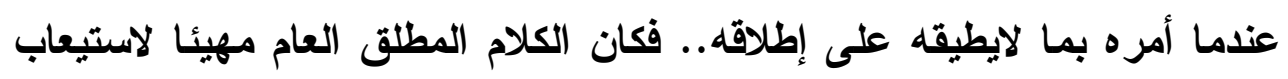
التفاصيل الضرورية فيما بعد.

وق بطرح الناصح الأسئلة على المنصوح؛ سؤالا، أو أكثر.. وتكون

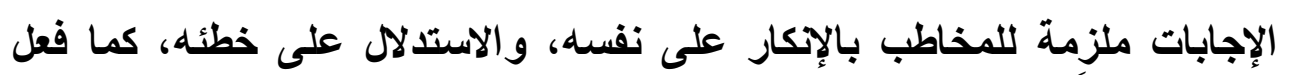

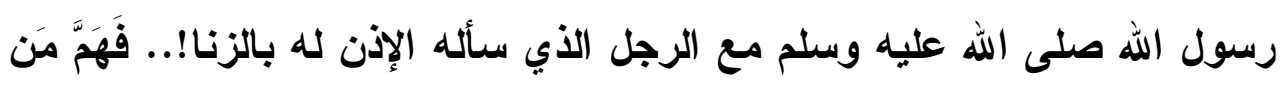

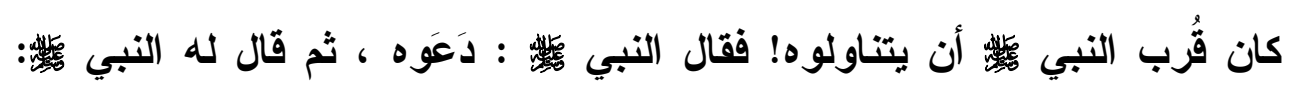

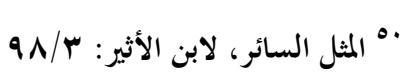

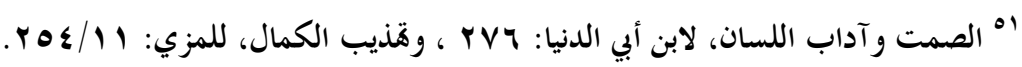

$$
\begin{aligned}
& \text { - vor - }
\end{aligned}
$$


أتحب أن يفعل هذا بأختك ؟ قال : لا ، قال : فبإبتتك ؟ قال : لا ، فلم يزل يقول

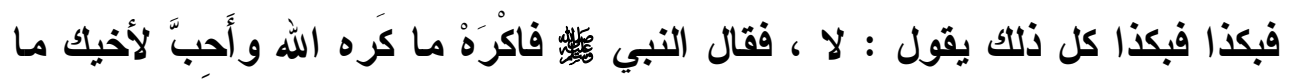
تحب لنفسك)

\section{المهارة الثالثة: المعرفة بالاحتمالات الممكنة جميعهان فيعها، وطرحها إن كان ذلك ضـروريا، ليكون المحاور على بينة في اختياره:} وهذا يسمى في البلاغة (حسن التقسيم)، وهو من علم البديع، ومعناه:

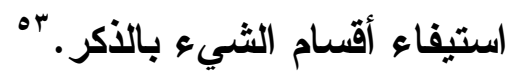

ومن أهم منافعه أنه يحول مركزية اتخاذ القرار إلى العقل، ويستبعد أو

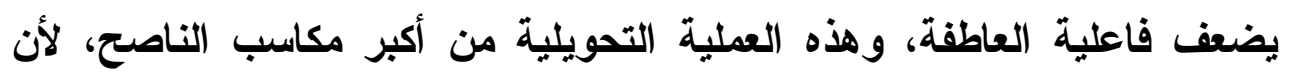

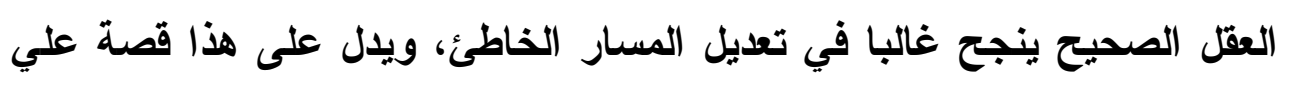

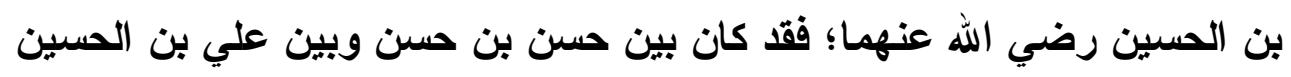

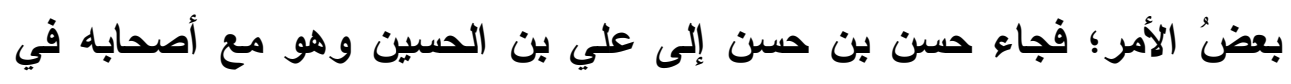

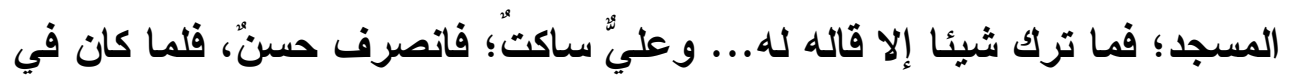

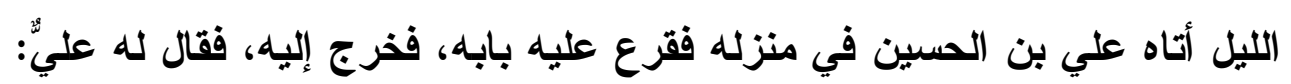

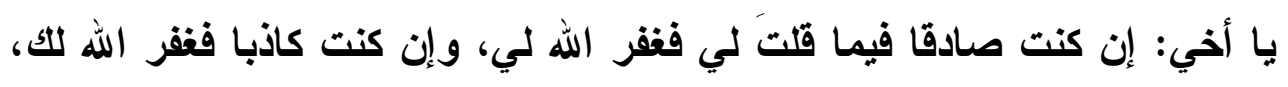

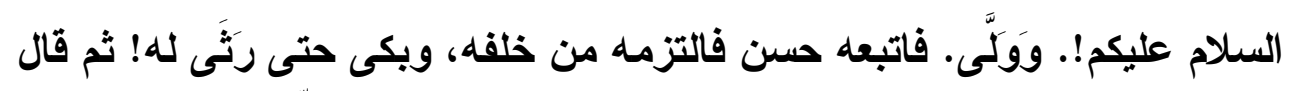

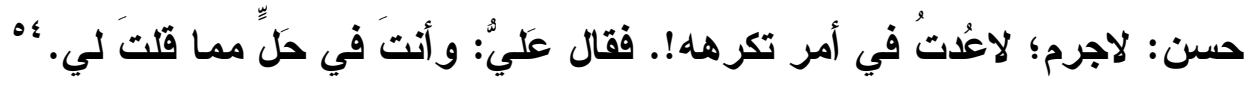

$$
\begin{aligned}
& \text { ror } \\
& \text { r الإيضاح للقزويني: }
\end{aligned}
$$

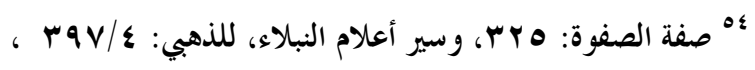

$$
\begin{aligned}
& -V 0 \varepsilon-
\end{aligned}
$$


وتحصل الصحة في التقسيم عندما تكون الأقسام المذكورة تامة لم يخل بشيء منها ولا تكررت ولا دخل بعضها في بعض ْْ .على نحو التقسيمات الله

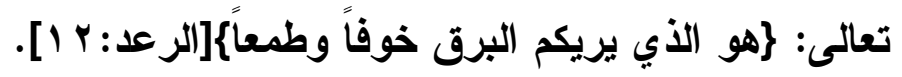

وقد يستعمل التقسيم في الحوار والمجادلة في فتوى شرعية، فيكون من

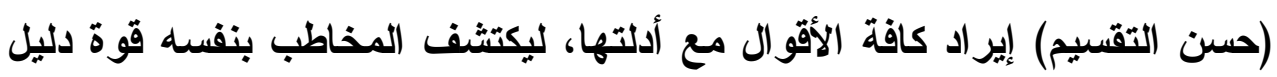
القول الراجح، ووهن ما سواه من الأقوال في المسألة..

إلا أنه إن كان المخاطب عاميا، أو ضعيف الاحتراز لاينه، فقل يلتبس عليه الأمر بكثرة الأقسام، أو يكون له فيها فتنة؛ فيحسن -حينئ- مساعدته في الاني

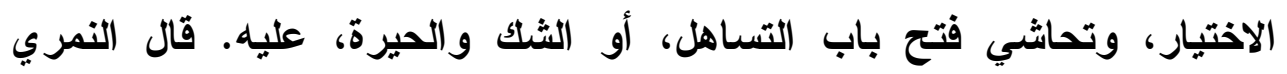

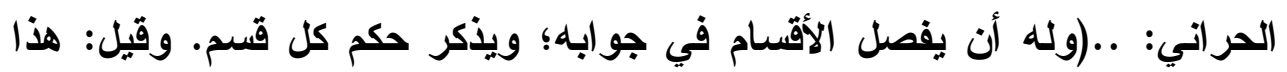

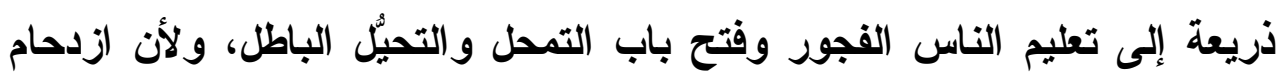

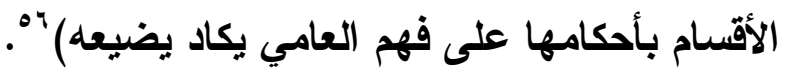

\section{المهارة الرابعة: (الاستدراج) في الحوار والمناقشـة:}

وهو من فنون علم البيع؛ بل عليه مدار جزء لا يستهان به من البلاغة

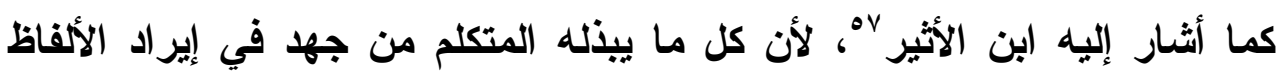

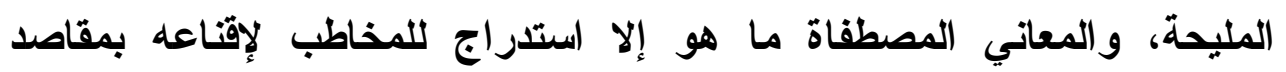

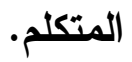

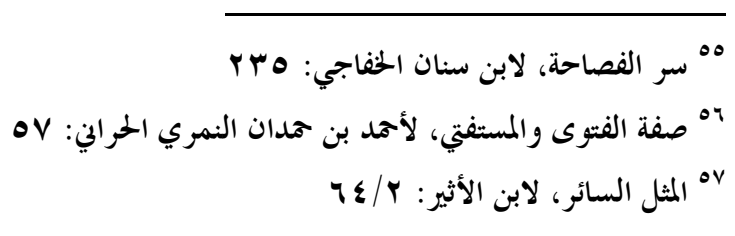


قال الثعلبي في تفسيره: (قال أهل المعاني : الاستدراج أن يدرج إلى الثيء

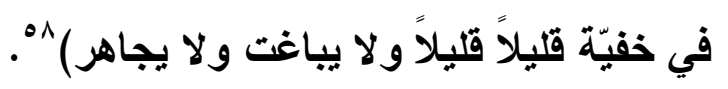

إلا أن البلاغيين خصصوا هذا المصطلح بأسلوب من أساليب الكلام، وهو

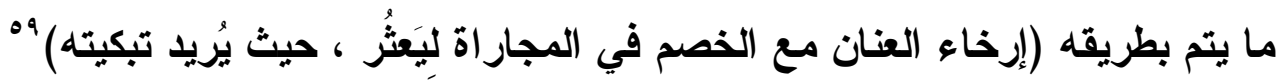

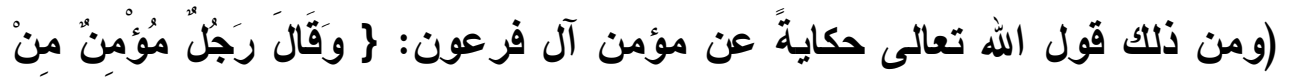

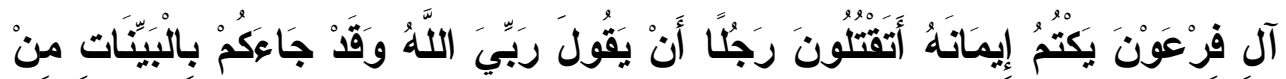

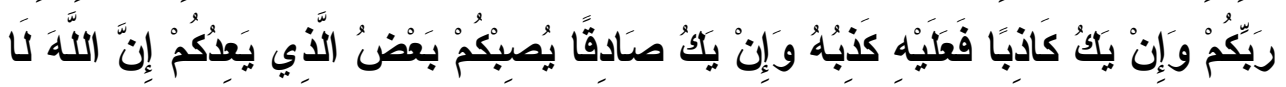

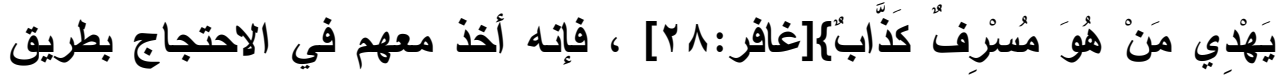

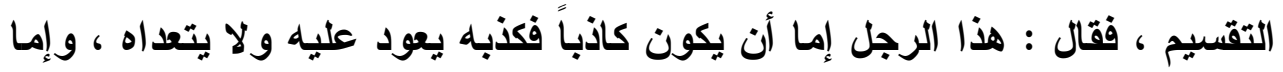

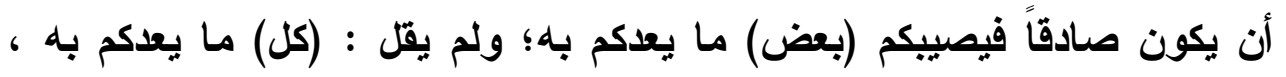

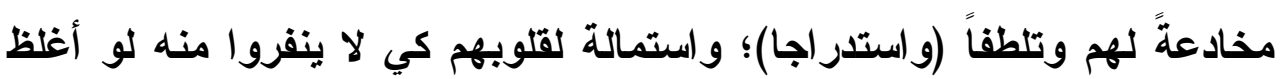
في القول ، وأظهز لهم أنه يهضمه بعض حقه.

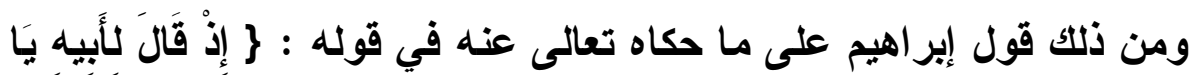

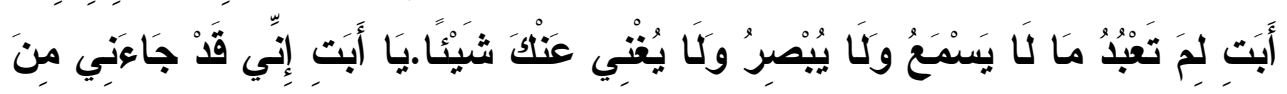

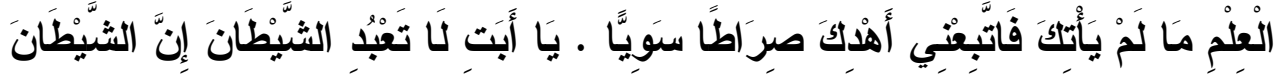

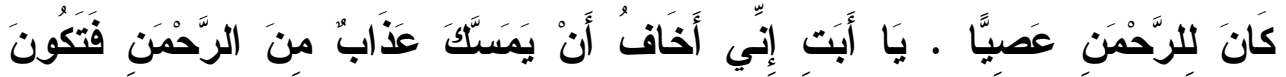

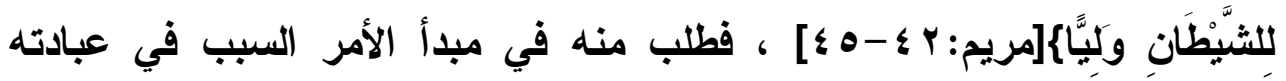

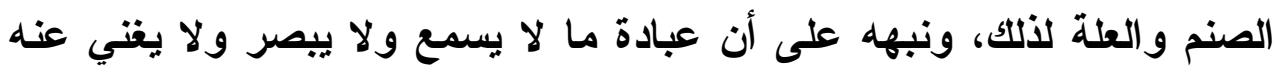

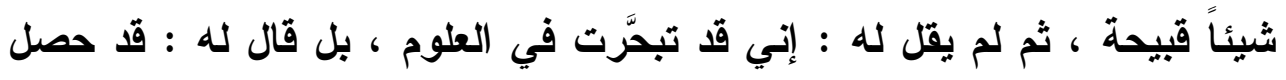

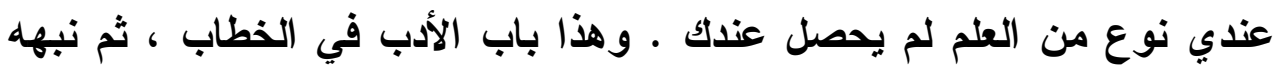

$$
\begin{aligned}
& \text { ^ه تفسير الثعالبي: \&/Y اب }
\end{aligned}
$$

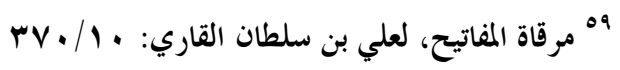




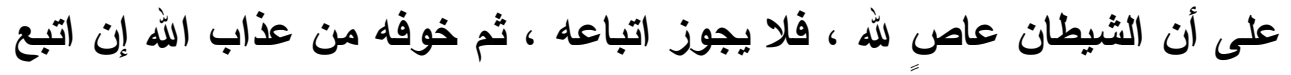
الثيطان ، وخاطبه في جميع ذلك بقوله : ' يا أبت ' ؛ استعطافاً و استدراجاً) ".

قال ابن الأثير: (وفي القرآن الكريم مواضع كثيرة من هذا الجنس لا سيما

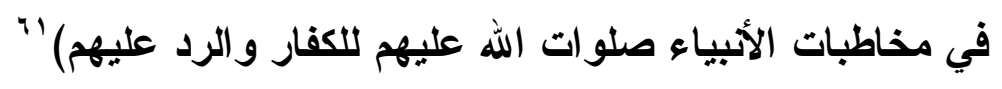

\section{المهارة المخامسـة: أسـلوب الإنصساف:}

\section{ويسميه بعض البيانيين: الكلام المنصف.}

وبه تتجلى للخصم ثقة المحاوِر بنفسه، (وهو : أن يذكر [المتكلمُ للمخاطب]

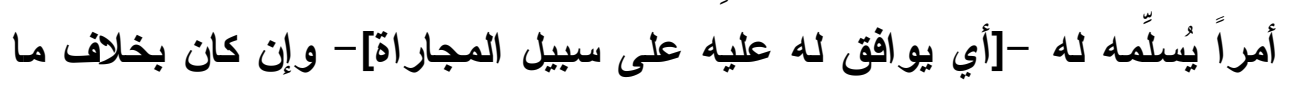

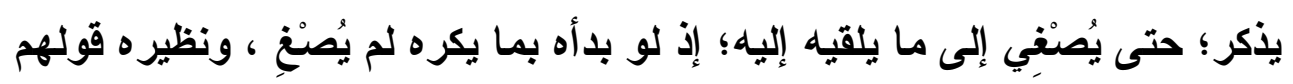

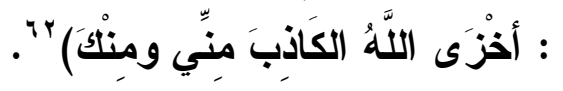

وبعبارة أوضح هو: أن تجعل الخصم حكما في الاختيار لنفسه، ليختار من

$$
\text { خيارين -أو أكثر - أحلاهما مر بالنسبة إليه. }
$$

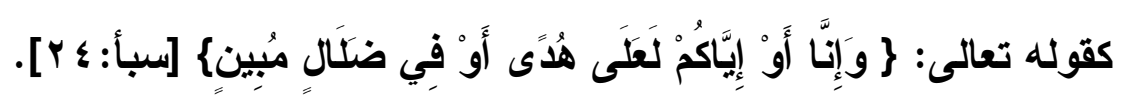

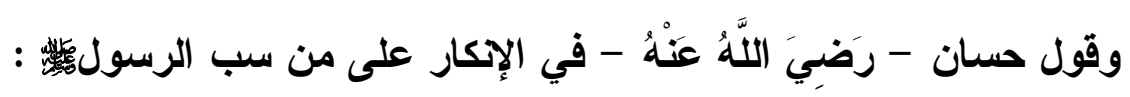

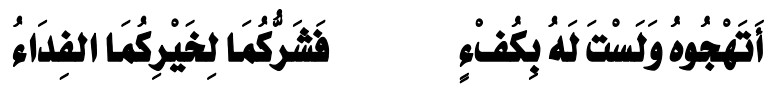

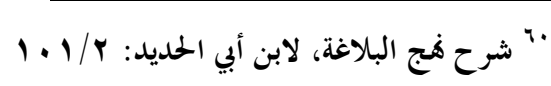

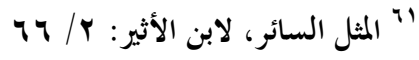

$$
\begin{aligned}
& \text { "r اللباب في علوم الكتاب، لابن عادل الدمثقي: } \\
& \text { - VOV - }
\end{aligned}
$$


ومنه أن رجلا شتم ابن عباس رضي الله عنهما، فقال ابن عباس: إنك

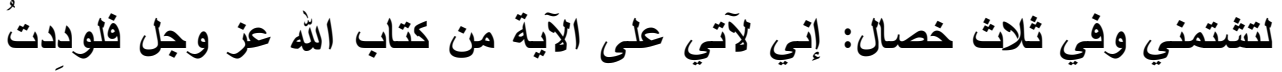

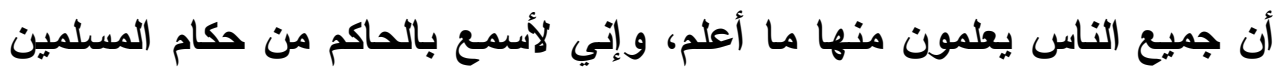

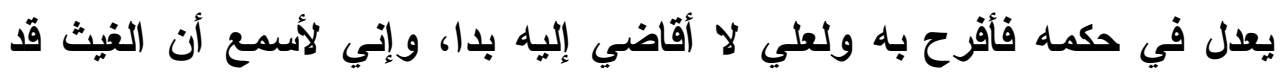

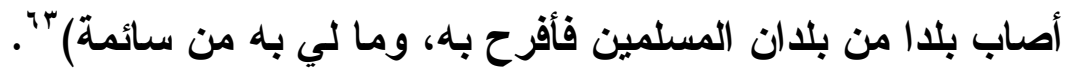

\section{المهارة السـادسـة: الاستـدلال المنطقي: (المذهب الكسلامي) :}

وهو من فنون علم البليع، عند علماء البلاغة. ؛"

و إنما نسب إلى (علم الكلام) لأن علماء الكلام استتدوا إليه أكثر من غيرهم، في مجادلاتهم." (وهو إيراد حجة تكون -بعد تسليم المقدمات- مستلزمة للمطلوب).

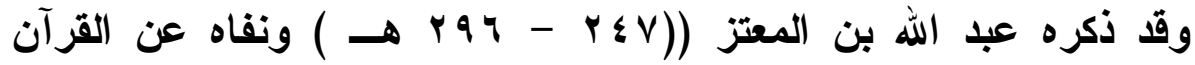
الكريم، لما فيه من التكلف، وهذا صحيح بالنسبة إلى الثواهد الثعرية التي

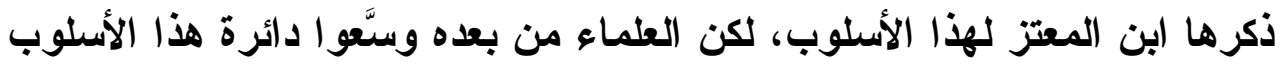
ليشمل أنواعا من الاحتجاج والاستدلال العقليين الخاليين من التكلف، ومن هناء لهان قالو بصحة وجوده في القرآن الكريم والحديث الثريف.

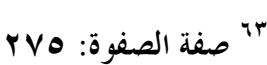

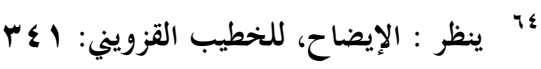

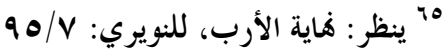

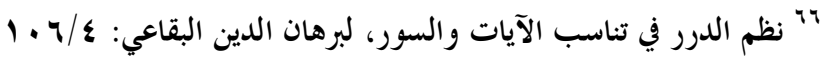

$$
\begin{aligned}
& \text { - V०N - }
\end{aligned}
$$


ولذا فإن الآمر بالمعروف والناهي عن المنكر قد يستعمله في بعض

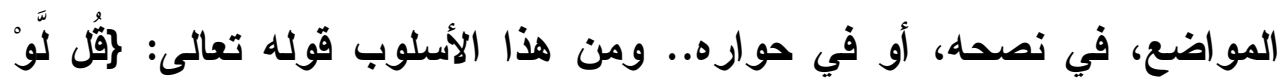

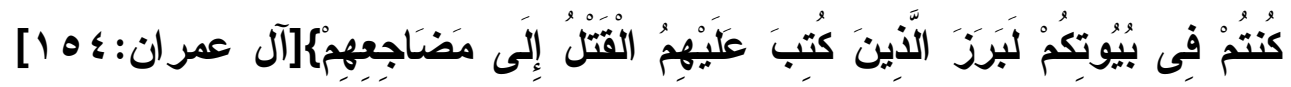

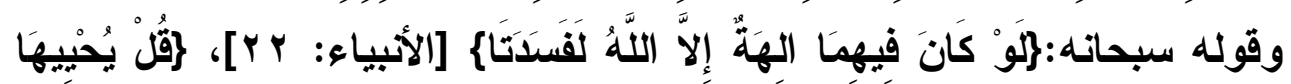

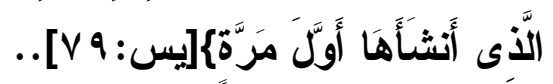

(ومنه قوله الإمام أحمد وغيره.

وتمام الاليل - في هذه الحديث-أن يقال: لكنكم ضحكتم كثيرا وبكيتم

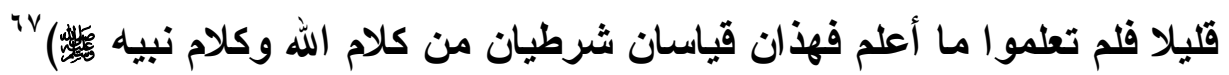

\section{وقوله كَ}

قال أبو حيان في تفسير البحر المحيط: (هذا النوع عند علماء البيان

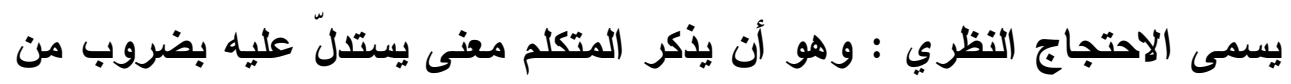

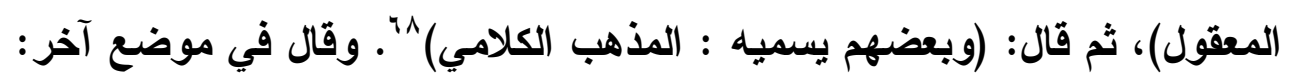

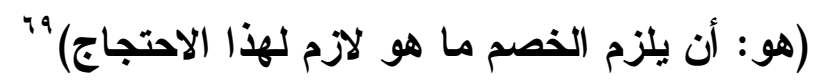

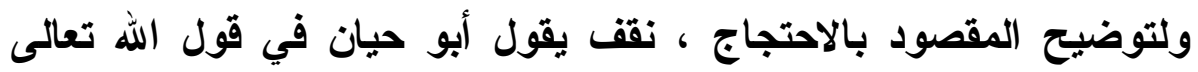

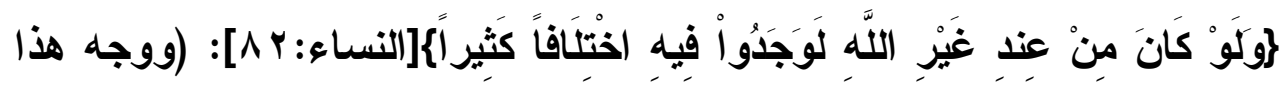

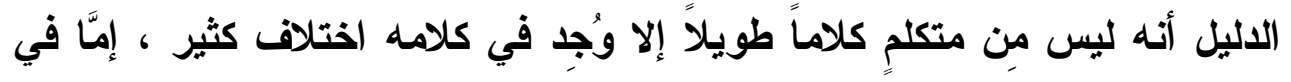
الوصف واللفظ ، و إمَّا في المعنى؛ بتناقض أخبارٍ ، أو الوقوع على كلى خلاف المخبرَ

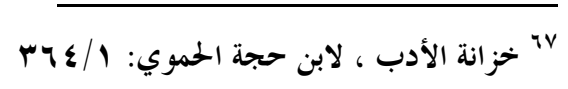

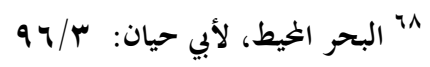

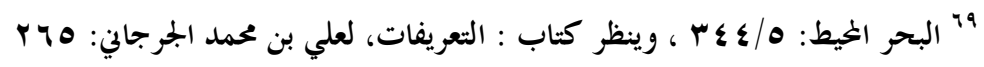

$$
\begin{aligned}
& \text { - V०q - }
\end{aligned}
$$


بهه ، أو الشتماله على ما لا يَتنئُ ، أو كونِه يمكن معارضتُه. و القرآن العظيم ليس

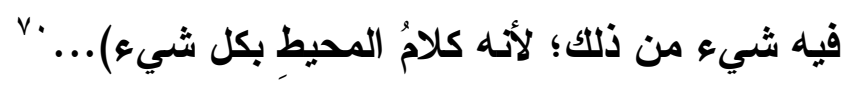

ولا بد من لزوم طريقة القرآن الكريم وأدبه وتطبيقات النبي الحكيم -صلى الكي

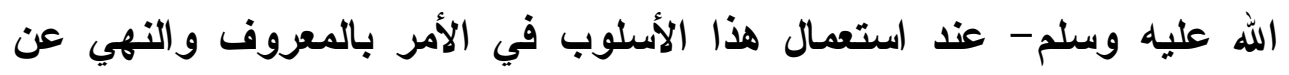

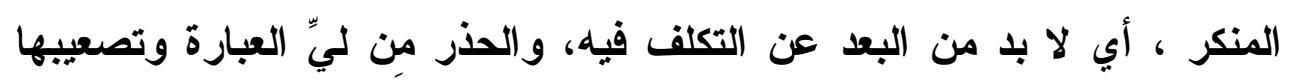

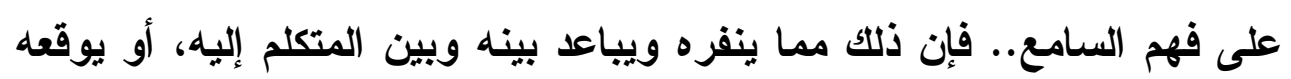
في التحيُر أو الثكت.. فتأتي نتائج هذا الأسلوب على فلى عكس المتوقع منه.

ومن الاقتداء بالقرآن في هذا الأسلوب ماحكاه أبو هلا العسكري، في

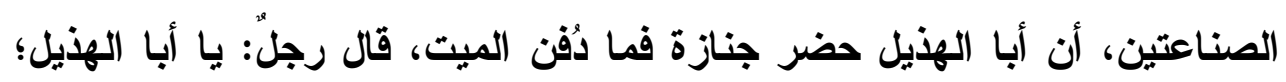

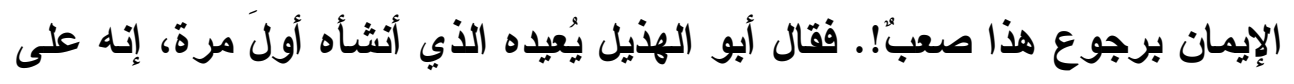
رجعه لقادر.

ومما ياخل في هذا الأسلوب التعليل للمأمور به، أو المنهي عنه، تعليلا

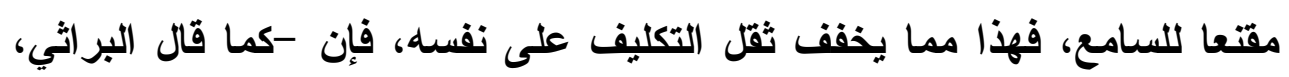

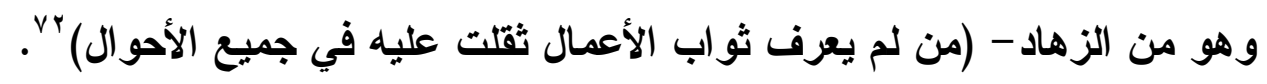

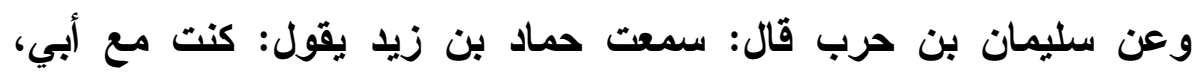

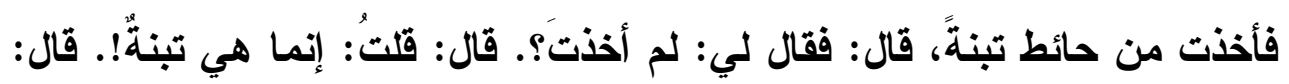

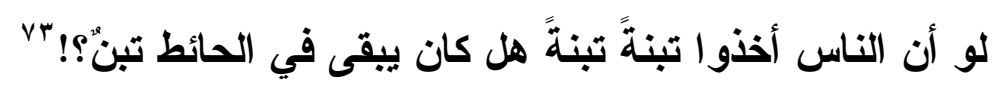

$$
\begin{aligned}
& \text { rv/ البحر الخيط: v/V. }
\end{aligned}
$$

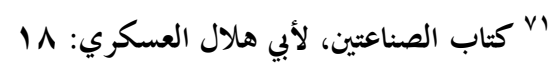

$$
\begin{aligned}
& \text { rr } \\
& \text { 19 كتاب الورع عن الإمام أمد بن حنبل، للمروزي: } 19 \\
& -174 .
\end{aligned}
$$




\section{المهارة السـابعة: لطف العبارة والأسـلوب:}

ويتمثل ذلك في تجنب العبارات الجارحة، والألفاظ السوقية النابية، واتخاذ

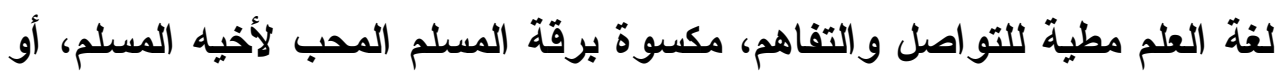
المسلم المشفق على الكافر من عذاب أليم.

وذلك مهما بلغ المخاطب في الحدة ، والاسترسال في الثدة..

يقول عبيد الله محمد أمين كردي: كان لقاء ما قبل الأخير مع سماحته في

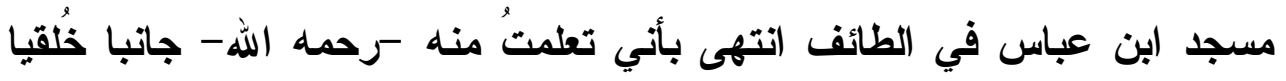

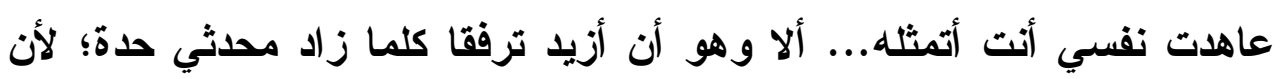

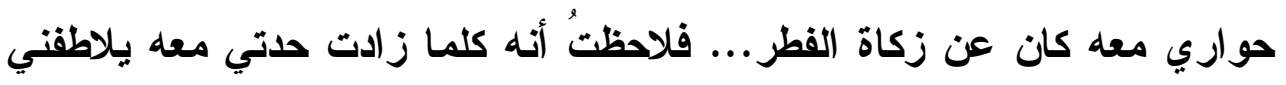

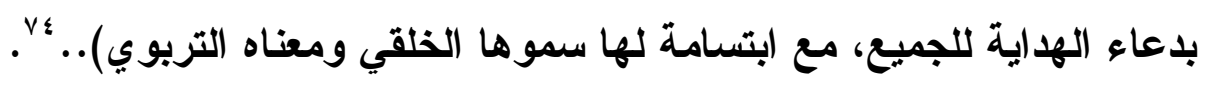
ومن مو اقف الثيخ ابن عثيمين رحمه الله أن طالبا خَطَّأ الثيخ صراحةً في

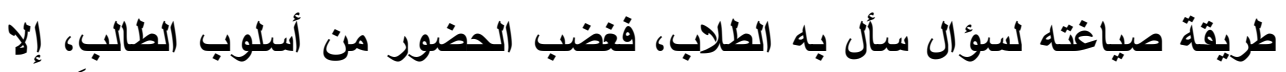

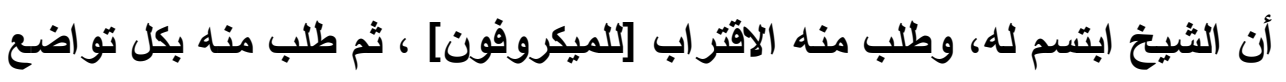

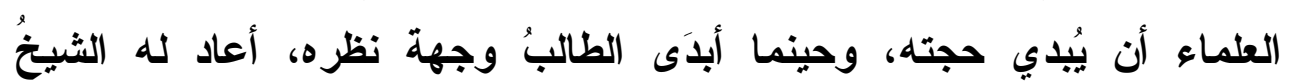

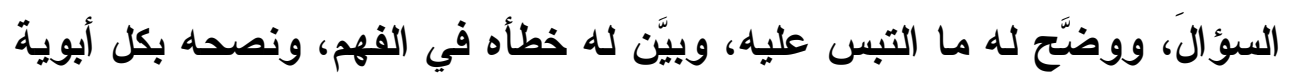

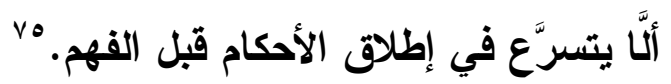

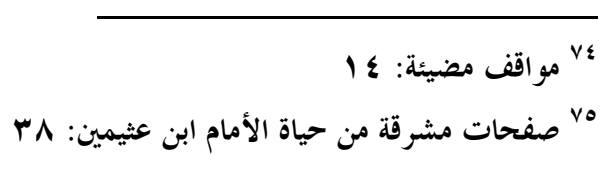




\section{الحخلاصة}

نستخلص مما سبق في هذا البحث أن المربي والموجه قلما يستغتيان عن

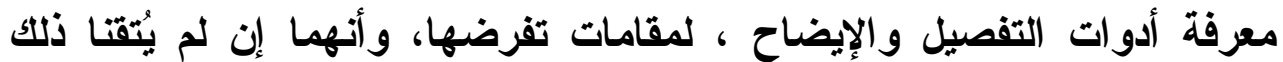
المطلوب فقد تأتي نتائج الجهود على خلاف المقصود.

وقد رأينا أن تلك الأساليب المعنية بالتعليم والمدارسة والتدريب مختلفة ومتنوعة؛ فمنها ما يتحقق عن طريق التصوير الفني للموقف أو الفكرة،

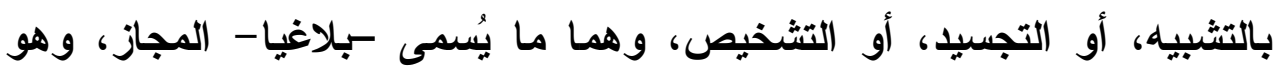
أنواع عديدة؛ منها الاستعارة، والتمثيل، و المجاز المرسل..

ومنها مايتحقق بطريق الإطناب المباشر؛ بأساليبه التي تحدث عنها

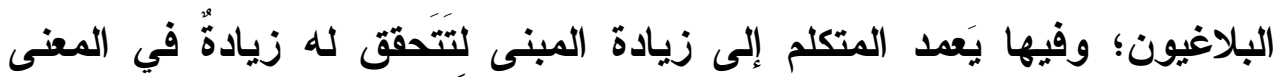

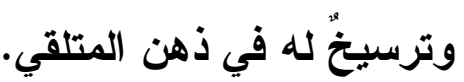

ومن التفصيل ما يُحققه الحوار والمناقثة، بشروطهما الأدبية والفنية التي

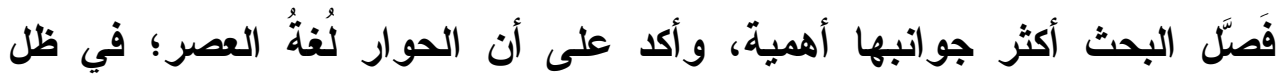

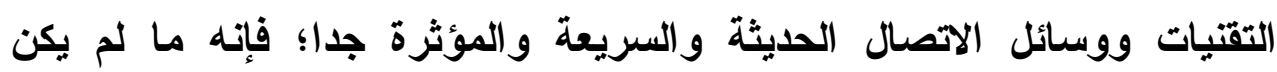

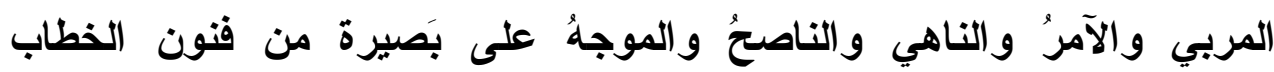

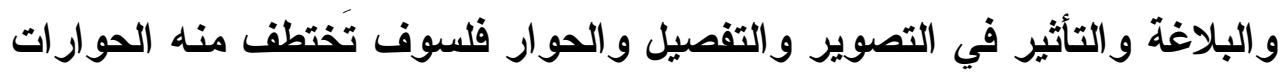
الأخرى هدفه، وتسبقه إلى فرض رؤيتها وتصورها الذي قد يكون مضادا، أو

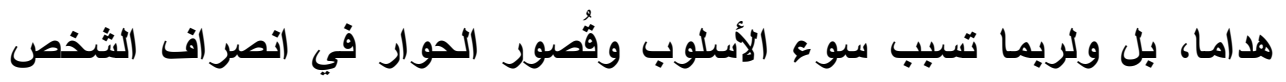
المستهف بالدعوة و التوجيه والتربية- عن الطريق الذي كان يختطه له المربي

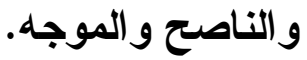


وقد عني هذا البحث عناية خاصة ومستمرة بربط القاعدة والأسلوب مع

تطبيقاته الممكنة، تقريبا لها وتوضيحا، و لغرض إزالة للبس، ودفعا لنقص التصور، حيث تفتقر بعض الاراسات إلى التطبيق وروحه وحياته، وهذا مما باعَد فيها الفجوةَ مع القارئ.

والله أسأل أن ينفعني وغيري بما قرأنا وكتبنا. 


\section{المصادر والمراجع}

الأمر بالمعروف والنهي عن المنكر لأبي بكر عبد الله بن محمد بن عبيا بن أبي الانيا تحقيق: صلاح بن عايض الشلاحي، الناشر: مكتبة الغرباء

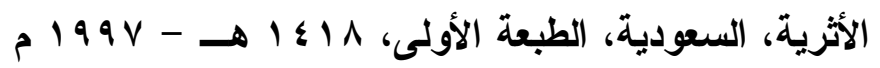

الإيضاح، للخطيب القزويني، تحقيق: محمد عبد المنعم خفاجي، الناثر :

$$
\text { دار الجيل - بيروت. ب/ت الإبات }
$$

الإخلاص والنية ، اسم المؤلف: أبو بكر عبد الله بن محمد بن عبيد بن أبي الدنيا، حققه وعلق عليه: إياد خالد الطباع، الناشر: دار البشائر،

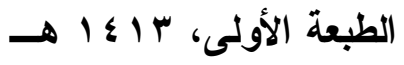

الأمثال من الكتاب والسنة ، اسم المؤلف: أبو عبد الله محمد بن علي

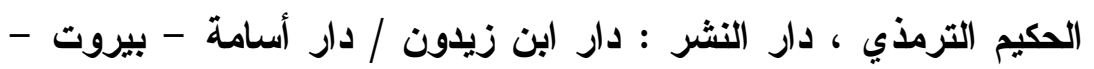

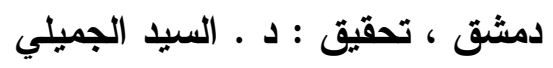

أسرار البلاغة ، عبد القاهر الجرجاني. قرأه وعلق عليه: محمود محمد شاكر . الناشر: مطبعة المدني بالقاهرة، دار المدني بجدة.

أضواء البيان في إيضاح القرآن بالقرآن، تأليف: محمد الأمين بن محمد بن المختار الثنقيطي ، تحقيق : مكتب البحوث والاراسات. دار

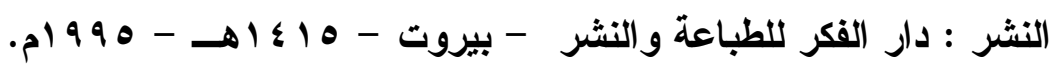

أنوار الربيع في أنواع البديع، لعلي بن أحمد بن محمد معصوم ، الشهير بابن معصوم 
البيان والتبيين ، للجاحظ ، دار النشر : دار صعب - بيروت ، تحقيق : فوزي عطوي.

التذكرة الحمدونية، لمحمد بن الحسن بن محمد بن علي بن

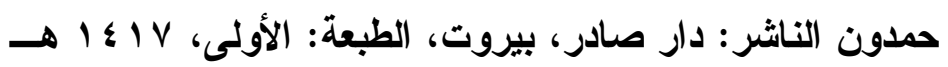
الجواب الأبهر لمن سأل عن الأمر بالمعروف والنهي عن المنكر، لفؤاد سراج الجواهر الحسان في تفسير القرآن ، لعبد الرحمن بن محمد بن مخلوف الثعالبي ، دار النشر : مؤسسة الأعلمي للمطبوعات - بيروت.

الحيوان ، للجاحظ، أبو عثمان عمرو بن بحر ، دار النشر : دار الجيل

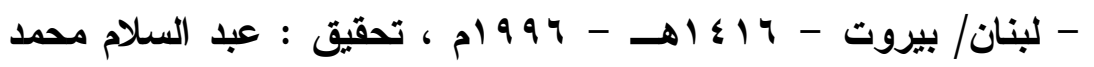
هارون

خزانة الأدب وغاية الأرب : لابن حجة الحموي؛ تقي الدين أبي بكر

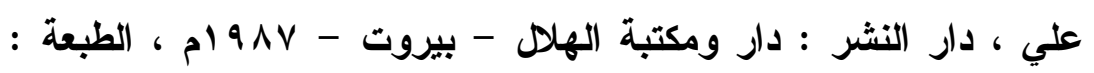

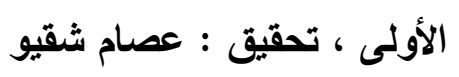

سير أعلام النبلاء ، للأهب؛ محمد بن أحمد بن عثمان، دار النشر :

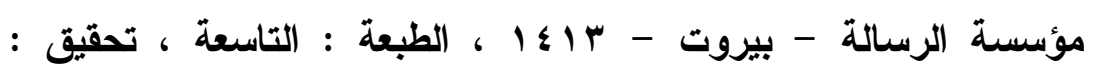
شعيب الأرناؤوط ، محمد نعيم العرقسوسي.

شرح صحيح البخاري ، لابن بطال: أبو الحسن علي بن خلف بن عبد

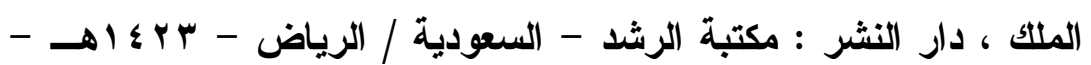

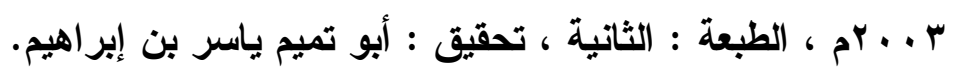


شرح نهج البلاغة ، لابن أبي الحديد: أبو حامد عز الدين بن هبة الله

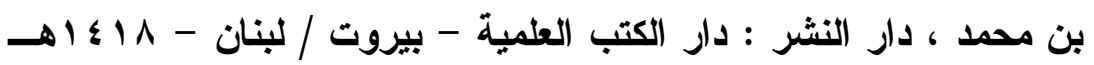
- 9191 ام ، الطبعة : الأولى ، تحقيق : محمد عبد الكريم النمري. الصمت وآداب اللسان ، لابن أبي الدنيا؛ أبو بكر عبد الله بن محمد بن

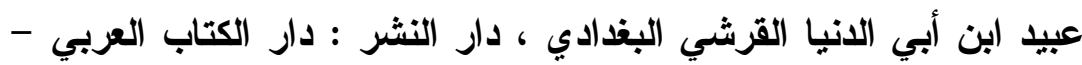
بيروت - · 1 1 ، الطبعة : الأولى ، تحقيق : أبو إسحاق الحويني صفة الصفوة، لأبي الفرج بن الجوزي، تحقيق: خالا طرطوسي، دار

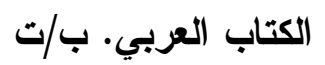
صفحات مشرقة من حياة الإمام محمد بن صالح العثيمين، تأليف: حمود عبد الله المطر. كتاب الزهد الكبير ، للبيهقي؛ أبو بكر أحمد بن الحسين بن علي بن

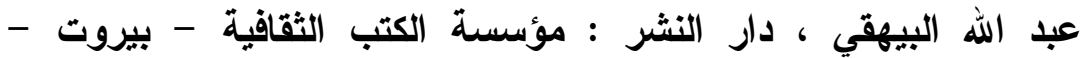
1999 199 ، الطبعة : الثالثة ، تحقيق : عامر أحمد حيدر. كنز العمال في سنن الأقوال والأفعال ، علاء الاين علي المتقي بن حسام الدين الهندي ، دار النشر : دار الكتب العلمية - بيروت 9 1 أهـ-19 99 ام ، الطبعة : الأولى ، تحقيق : محمود عمر الامياطي. كتاب الصناعتين الكتابة والثعر ، لأبي هلال الحسن بن عبد الله بن سهل العسكري ، دار النشر : المكتبة العصرية -بيروت - 7 . ـ اهـ-

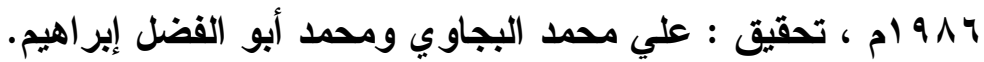
الكثاف عن حقائق التززيل وعيون الأقاويل في وجوه التأويل ، للزمخشري؛ أبو القاسم محمود بن عمر الزمخشري الخوارزمي ، دار 
النشر : دار إحياء التراث العربي - بيروت ، تحقيق : عبد الرزاق

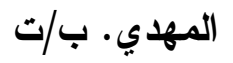

اللباب في علوم الكتاب ، لأبي حفص عمر بن علي ابن عادل الامشقي الحنبلي ، دار النشر : دار الكتب العلمية - بيروت / لبنان - 9 إئ 19 هـ - 9 ام ، الطبعة : الأولى ، تحقيق : الثيخ عادل أحمد عبد الموجود والشيخ علي محمد معوض.

المثل السائر في أدب الكاتب والشاعر ، لابن الأثير؛ أبو الفتح ضياء الدين نصر الله بن محمد بن محمد بن عبد الكريم ، دار النشر : المكتبة العصرية للطباعة والنشر - بيروت - 999 ام ، تحقيق : محمد محي الاين عبد الحميد

مرقاة المفاتيح شرح مشكاة المصابيح ، لعلي بن سلطان محمد القاري ،

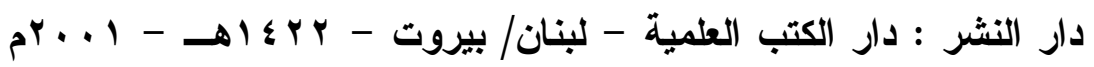
، الطبعة : الأولى ، تحقيق : جمال عيتاني.

مواقف اجتماعية من حياة الشيخ العلامة عبد الرحمن بن ناصر السعدي: محمد السعدي، ومساعد السعدي.

مواقف مضيئة في حياة الإمام عبد العزيز بن باز ـ تأليف: حمود المطر • دار الوطن.

مفتاح العلوم، يوسف بن أبي بكر السكاكي، ضبطه وكتب هوامشه وعلق عليه: نعيم زرزور، الناشر: دار الكتب العلمية، بيروت - لبنان،

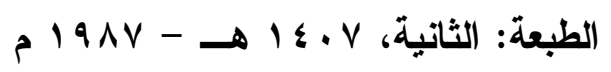


نقد الثعر، قدامة بن جعفر بن قدامة، الناشر: مطبعة الجوائب ـ

$$
\text { قسطنطينية، الطبعة الأولى. }
$$

نظم الدرر في تناسب الآيات والسور: برهان الدين أبي الحسن إبراهيم

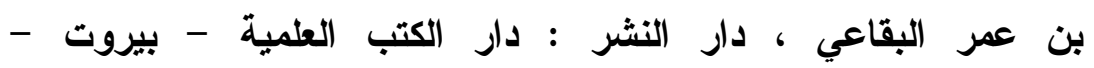

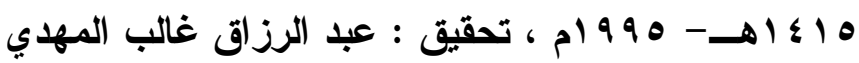

الورع ، ابن حنبل؛ أحمد بن محمد بن حنبل الثيباني أبو عبدالله ،

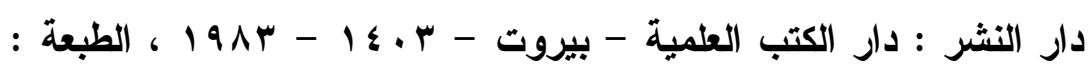

الأولى ، تحقيق : د. زينب إبراهيم القاروط 